\title{
Article
}

\section{GIS and Remote Sensing Based Physical Land Suitability Analysis for Culitivation OF Selected Cool Weather Cereal Crops, Misha District, Hadiya Zone, South Central Ethiopia}

\section{Solomon Abebe ${ }^{1}$}

1, Department of Geography and Environmental Studies, Jimma University, Ethiopia.

2, Department of Natural Resource Management, Wachamo University, Ethiopia.

*Corresponding author address: Email: Solomon10abebe@gmail.Com Tel +251916718390

\begin{abstract}
This study to assess the Physical Land Suitability Analysis for Cultivation of Selected Cool Weather Cereal Crops, Misha District, Hadiya Zone, South Central Ethiopia of major cereal crops of barley and teff in Misha district. Each of the criteria was separately reclassified and analyzed for their suitability for supporting barley and teff crops based on the FAO crop requirements specified for them. The major data sources were climatic data, soil, LGP and topographic data as well as key informant interview, questioner observation of crop requirements which have been considered to undertake suitability assessments of the study area. The factor maps like land use /land cover, temperature, rain fall, soil type and altitude were classified based on suitability evaluation methods of FAO and experts' opinion. At final stage these were reclassified and standardized in GIS software extension tools, which led to the preparation of suitability analysis map of the major crops plant suitability classes. As part of spatial MCDM, AHP pair wise comparison module was used to derive internal and external weights for each individual factors and parameters respectively. Consequently, suitability analysis was done and weighted overlay suitability map was visualized with integration of GIS. The findings show that among total area of land suitability maps for both barley and teff cops were using weighted overlay techniques. The suitability map of teff crop shows that 12,038.22 hectare of the investigated area are highly suitable (S1), 19,646.07 hectare moderately suitable (S2) and 4,501.71 hectare marginally suitable (S3) and 112 hectare not suitable. On the other hand, the suitability map of barley crop shows that 7,898.52 hectare of the investigated area are highly suitable (S1), 22,830.08 hectare moderately suitable (S2), and 5,466.4 hectare marginally suitable (S3) and 103 hectare not suitable for economic reasons (N1). This was done for barley and Teff crops separately. Results of the study revealed that most of the lands in the study area are suitable for the cultivation of the selected crops and other crops. Based on finding, it could be recommended that this work would be used as policy guide for planners; investment could be successful in the District, further suitability research works should be carried out in order to optimize the major crop cultivation and production.
\end{abstract}

Keywords; Land Suitability Analysis; Major crops; Land Management practice

\section{Introduction}

Agriculture is one of the World's most important activities supporting human life. On a global scale, agriculture has the proven potential to increase food supplies faster than the growth of the Population, a pattern to be expected in the foreseeable future [1]. [2] World population of 7.2 billion is projected to increase by 1 billion over the next 12 years and reach 9.6 billion by 2050, which points out that growth was mainly in developing countries, with more than half in Africa. Thus, there is growing concern about food security in Africa and especially in Sub-Saharan Africa. While the aggregate global food supply/demand picture is relatively good, there was a worsening in food security in Sub- Saharan Africa [3]. Therefore, evaluation of land suitability which has great physical and chemical land qualities is very needed to contribute to the World's food production in general and the country, Ethiopia, in particular to improve food security. 
Agricultural productivity in Ethiopia has not kept pace with population increase, and the region is now in a worse position nutritionally than it was 30 years ago: Food production has achieved a growth of about $2.5 \%$ per year, while population has risen at a rate of over $3 \%$ per year [4]. With the increase in population, as well as human activities, pressure on land has been intensified. In Rain Fed agriculture production systems, natural resources need to be used in such a manner that the productivity potential of the farm land is optimized. In Ethiopia, agricultural land suitability analysis is very important since agriculture accounts on average for about $46.3 \%$ of Gross Domestic Product, $83.9 \%$ of exports and $80 \%$ of the labor force [5]. The same source indicated that Ethiopia has great agricultural potential because of its vast areas of fertile land, diverse climate, generally adequate rainfall, and large labor force.

Despite this potential, however, Ethiopian agriculture has remained underdeveloped because of drought, a poor economic base, and low level of technologies on agricultural application. Moreover, such a kind of analysis allows identifying the main limiting factors for the agricultural production and enables decision makers such as land users, land use planners and agricultural support services to develop a crop management able to overcome such constraints and increasing the productivity [6]. Suitability analysis can answer the question. [7] Most of research are conducted on approaches of land evaluation in different perspectives as it is studied by [8] land suitability can be determined by climatic situation, terrain data and soil properties which focuses on specific evaluation from ranging from highly suitability to not suitably. This study is also supported by [9] in which the argued that suitability of land is assessed considering rational cropping system, for optimizing the use of a piece of land for a specific use. But this approach is challenged by researchers like [1] used an approach of land capability evaluation for general agricultural purpose rather than for specific land use types. Although barley and teff are the staple food of most Ethiopian, the present production system cannot satisfy the customers demand because Ethiopian farmers use traditional, backward farming system and less to know which parts of the land suitable in each crops which is not supported by modern technology [10] . This should be supported by modern research based productions in the area by the farmers. Thus guiding literatures shows land suitability, the use and its methods. Though there are researches on the area, all the theories as per the researchers thinking is not enough when we compare the necessity of study. This may needs to go further in transforming traditional based agriculture production system to modern system.

The study was carried out focusing on the scientific practices of improved suitability analyses of farmland in the study area. Though the environment is a major area of production for the selected crops and the necessity of the cereals is there, as farther investigator knowledge is concerned. This fact in addition with the fact that the production of major crops in the area is done without the use of modern technology has not seen getting attention of the concerning bodies, motivates the researcher to conduct research on land suitability for selected cereals so as to identify the parts of land those are more suitable for production of major crops on the study area. Thus identifying the current land use management system may merit the researcher to encourage the best use of current land use and identification of hindering factors of land use helps the process of picking up the basic challenges those need to be supported by scientific finding of the paper was conducted on the area.

\section{Materials and Methods}

Misha district is found in SNNP Regional State, Hadiya Administrative Zone, and located $248 \mathrm{~km}$ south west of the capital Addis Ababa, and $228 \mathrm{~km}$ north-west of Hawasa the regional capital of SNNPRS and $18 \mathrm{KM}$ far from Hosanna Town. It extends between 7036"8' - 7055"1' North latitude and 37039"30'up to 3849"03' East longitude. Also it is bounded to the south and east by Lemo Woreda, to the west by Gomboro and Gibe Woreda, from the east by Silte zone, and from north bounded by Gurage zone and Yem special Woreda. 
Page $\mathbf{3}$ of $\mathbf{2 3}$

\section{FIGURE 1: LOCATION AND TOPOGRAPHY OF THE STUDY AREA}

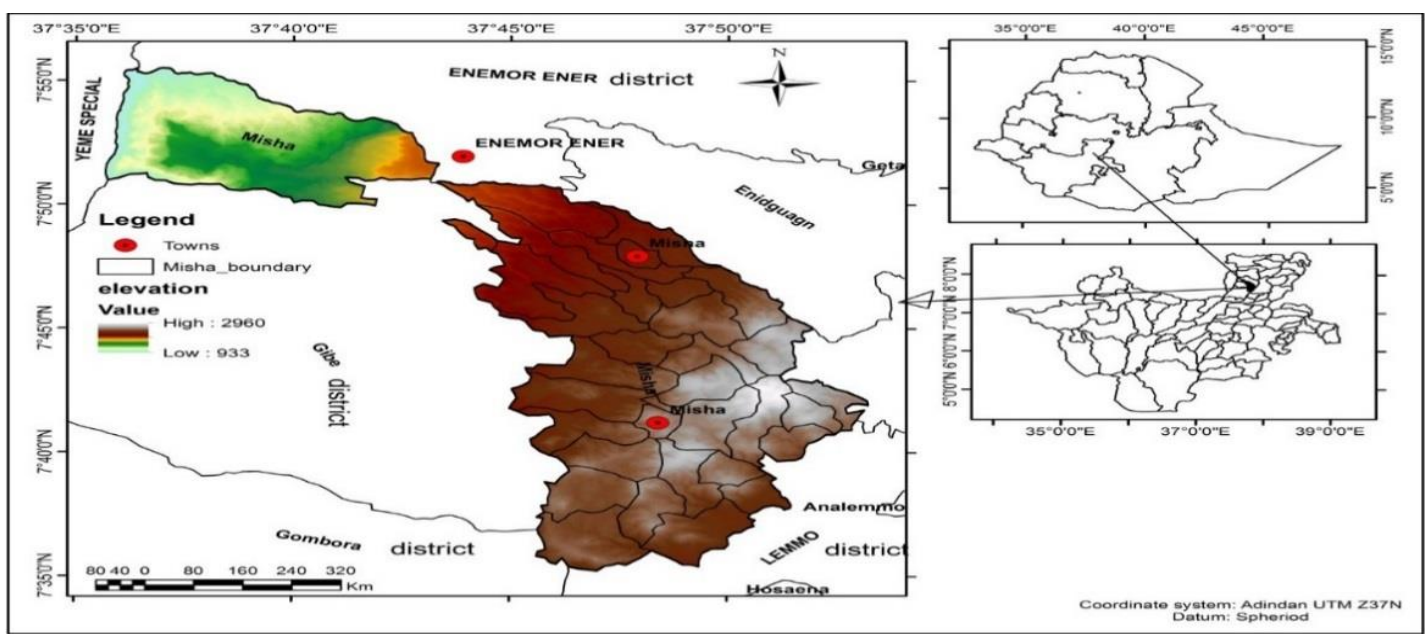

Source: Field Work, 2018

According to [11], patterns of livelihood clearly vary from one geographic location to other. Factors such as climate, soil, access to market etc. all influences livelihood patterns Misha Districts and it's surrounding as one of Ethiopia and still are dominated by agricultural lands such as cereal crops and pules production. In the study area agriculture is the main economic activity which account ninety five percent and five percent from trading. Over all off districts coverage $76 \%$ are cultivated land. The agro climatic zone of the study area ranges from According to [12] classification, agro-ecology of Ethiopia is classified as: Dega, Weinadega, and Kola. The rainfall distribution is uni-modal having one rainy seasons per year which means maximum rainfall from first June to the end of August and minimum rainfall. Major soil associations are classified on the basis of predominant chemical and physical properties, derived from parent materials and modified by weathering and other transformative processes.

FIGURE 2: SOILS AT THE STUDY ARE

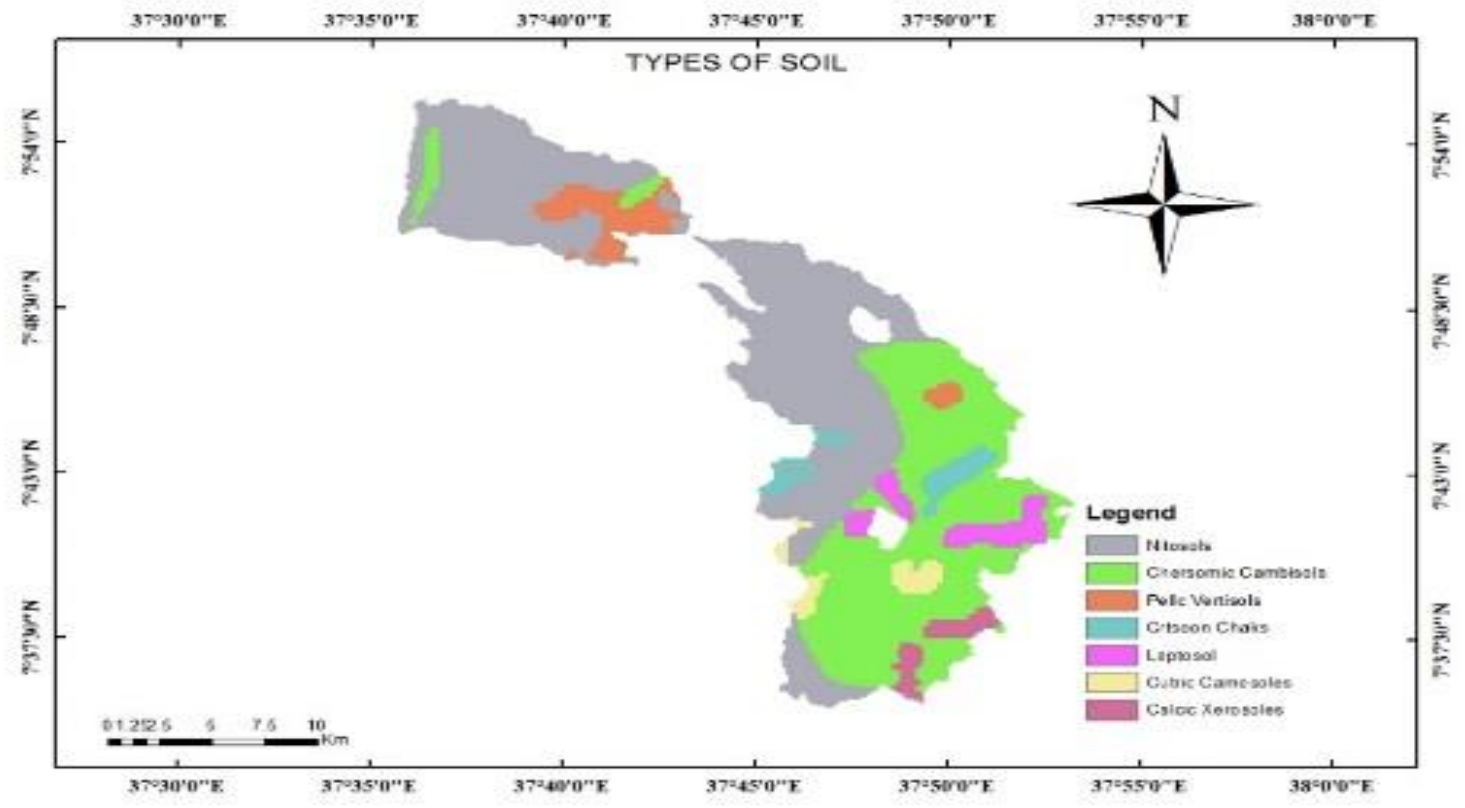

Source: Field Work, 2018

Figure 3: General Methodological Flow Chart 
Page 4 of $\mathbf{2 3}$

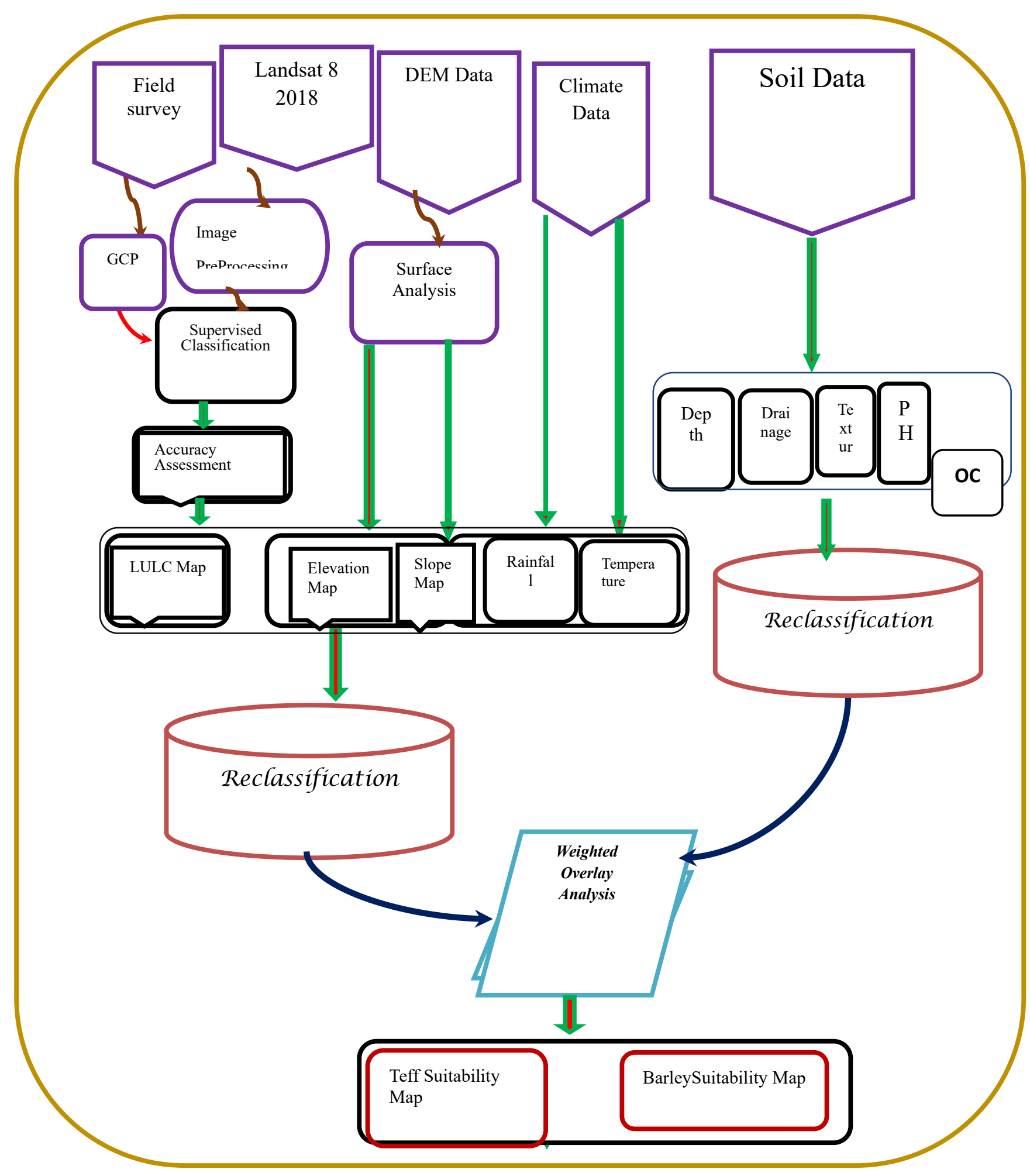


Thus a methodology of GIS, SMCDM and AHP based land suitability analysis used to determine the suitability of barely and teff crop cultivation in Misha District by using factors such as LU/LC, climate (temperature and rainfall) altitude and soil type characteristics of the area. When a given crop suitability was carried out; area coverage, importance of the crops in the livelihood of the concerned community, suitability of soils and agro climatic conditions of the study region is always considered. The cropland use requirement (LURs) was also selected based on agronomic knowledge of local experts and [8] guidelines.

The research results evidence that the comparison of current land use highly and moderately suitable land surface for major crops cultivation are already being used in the area for barely and teff agriculture cultivation. Multi criteria decision making is defined as a process that combines and transforms a different spatial data inputs into a resultant decision output as described in [13]. Spatial MCDM is more complicated and hard in contrast to conventional MCDM, as large numbers of factors need to be identified and considered, with high association of relationships among the factors [14].

Being an issue of multi-criteria decision-making process, major crops suitability demands for visualization of the impact of the alternatives and criteria in the form of maps. This requires can be accomplished effectively by the integration of spatial analysis and conventional multicriteria evaluation techniques. Moreover, environmental decision problems are characterized of having multiple and often contradictory objectives. When evaluating such a complex phenomenon, the spatial dimension seems to be the big hurdle. Here, the integration of GIS and MCDM techniques becomes useful. To come up with relative influence of weights of criteria and sub criteria, Analytical Hierarchy Process (AHP) approach in MCDM was used. In order to calculate the weights for criteria and sub- criteria, pair wise comparison matrix was structured by using data obtained from different experts and literatures; each and every factor were compared with the other factors relative to its influence on a scale from 1/9 to 9 in tabular format that was introduced by [15]

IDRISI software decision wizard software component was used to support multi criteria in which evaluation process multilayer were aggregated to yield a single out suitability overlay map. The weights were developed by providing a serious of pair wise comparison matrix of the relative importance of the factors to the suitability of pixels for the activity was analyzed. The pair wise matrix comparisons were then analyzed to produce a set of weights that sum to one. The procedures by which the weights were produced follow the logic developed by Saaty under the analytical hierarchy process (AHP). The responses of KII on ordering, weighting and rating the influence of the considered factors were analyzed inform of table under criteria standardization table.

\section{Results}

The type of land use/land cover (LULC) in the study area included Cultivable land, forest land, woodland, and open area land. This is to classify image pixel in to its belonging spectral resolution class. This parts are crop land, wood land, forest and open area as written in table 1 below. These all LU/LC were classified with high level of accuracy. The land use/cover of the study area was classified with over all accuracy of $0.91 \%$ and kappa coefficient of $0.88 \%$.the calculated value of the kappa coefficient 88 of land use land cover classification of the study area was acceptable to proceed for the next step of the work. 
Page 6 of 23

FIGURE 4 : LU/LC (A) AND SUITABILITY MAP OF LU/LC FOR TEFF AND BARLEY IN THE STUDY AREA
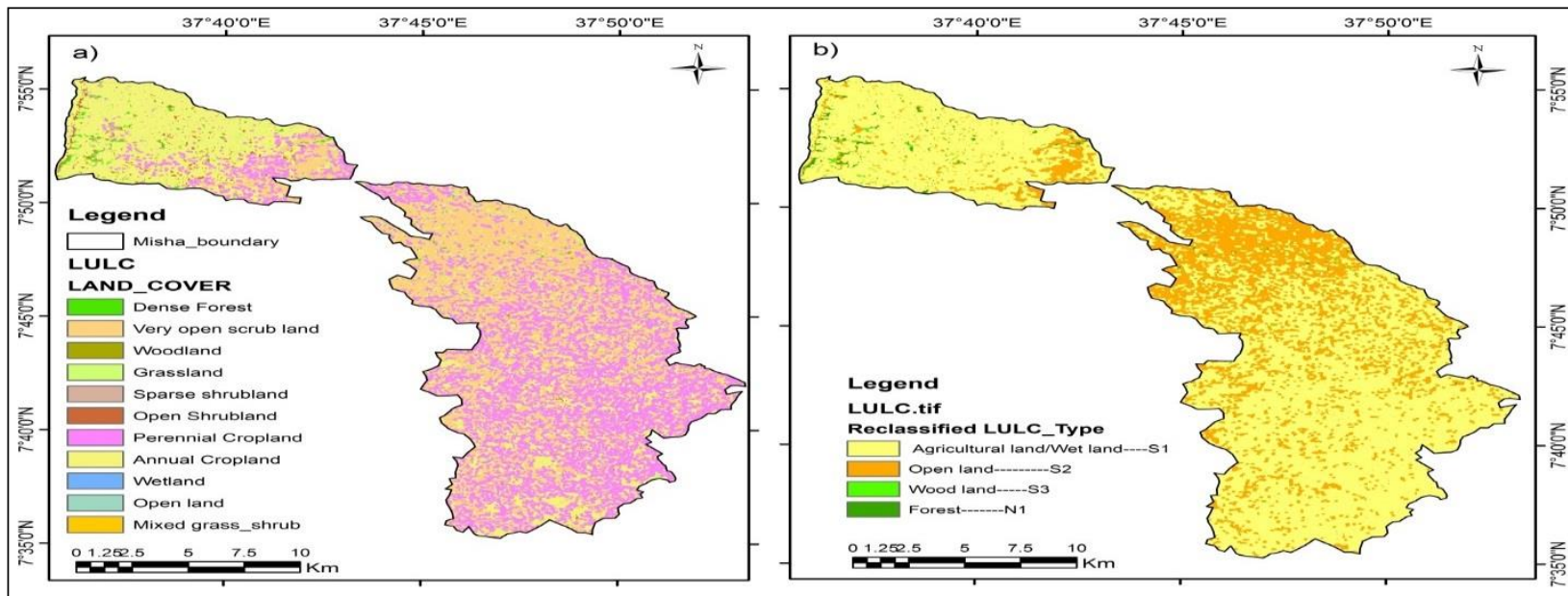

Source: Field Work, 2018

TABLE 1: ACCURACY ASSESSMENT OF LANDSAT 82018 CLASSIFICATION

\begin{tabular}{clccccc}
\hline No & LU/LC & Agriculture & Forest & Wood land & Open area & Total \\
\hline $\mathbf{1}$ & Agriculture & $\mathbf{4 3}$ & $\mathbf{2}$ & $\mathbf{0}$ & $\mathbf{2}$ & $\mathbf{4 7}$ \\
\hline $\mathbf{2}$ & Forest & $\mathbf{0}$ & $\mathbf{3 9}$ & $\mathbf{0}$ & $\mathbf{0}$ & $\mathbf{3 9}$ \\
\hline $\mathbf{3}$ & Wood land & $\mathbf{1}$ & $\mathbf{0}$ & $\mathbf{1 2}$ & $\mathbf{0}$ & $\mathbf{1 3}$ \\
\hline $\mathbf{4}$ & Open area & $\mathbf{2}$ & $\mathbf{0}$ & $\mathbf{2}$ & $\mathbf{1 6}$ & $\mathbf{2 0}$ \\
\hline Total & & & & & & \\
& & 46 & 41 & 14 & 18 & 120 \\
\hline
\end{tabular}

Source: Field Work, 2018

Over all accuracy (the same of the diagonal numbers) $\div$ (total pixel) $48+39+12+16=110 \div 120=0.91$ User accuracy $43 \div 47=0.914$ Producer accuracy $43 \div 46=0.934$ the diagonal number value shows correctly classified land use pixel whereas zero tells about the absence of interferences in the classification. The overall accuracy was calculated by dividing the total same of correctly classified pixels by total sum of pixel value in the error matrix. This values 0.91 or $91 \%$ when multiplied by $100 \%$.kappa coefficient measure the agreement between the classifications on the map and the reference data or GPS. The classification is acceptable then can proceed to the next further for work. The kappa coefficient calculation result in 0.88 or $88 \%$ after multiplying by $100 \%$. According to Adam et.al 2013, the kappa coefficient calculation result of LU/LC classification in the study area represents strongly agreement. Agricultural land cover class this land type is dominant as compared to other land cover or use type in the study area. Most area of Dega and Weinadega agro ecological zones grow different types of crops it cover $26,755.55$ ha which is $73.71 \%$ of the total area of the district.as it was described in crop land. The forest cover is mainly observed in the Dega (highland) and Weinadega (midland) agro ecological zone of District .It covers $9184.05(25.30 \%)$ of the area. The total land covered of wood land is 138.5 ha $(0.38 \%)$ of total land area of the study district which consists of multi stemmed woody species with a height of more than $2 \mathrm{~m}$. Open area LULC class covers 219.9 ha (O.61\%) the area. It is dominantly found at kola agro ecological zone of Misha district.

\section{TABLE 2: DATA TYPES, SOURCES AND RESOLUTIONS}

\begin{tabular}{lllcccc}
\hline No & Variables & Data type & $\begin{array}{l}\text { Resolution } \\
(\mathrm{m})\end{array}$ & $\begin{array}{l}\text { Resample } \\
(\mathrm{m})\end{array}$ & $\begin{array}{l}\text { Data } \\
\text { source }\end{array}$ & Remark \\
\hline 1 & Elevation & DEM/raster & $30^{*} 30$ & Original & USGS & \\
\hline 2 & Soil data & Vector & - & $30 * 30$ & FAO & \\
\hline
\end{tabular}


Page 7 of $\mathbf{2 3}$

\begin{tabular}{cccccc}
\hline 3 & $\begin{array}{l}\text { Meteorological } \\
\text { data }\end{array}$ & Raster & $1 \mathrm{~km}$ & $30 * 30$ & Worldclim.com \\
\hline 4 & Landsat8 2018 & Raster & $30 * 30$ & Original & USGS \\
\hline 5 & KII & Qualitative & - & & \\
\hline
\end{tabular}

Source: Field Work, 2018

TABLE 3: DESCRIPTION OF MAJOR CROP SUITABILITY (BASED ON EXPERTS' KNOWLEDGE AND GIZACHEW, 2014)

\begin{tabular}{|l|l|l|}
\hline Code & Class & Characteristics \\
\hline S1 & High Suitable & $\begin{array}{l}\text {-Land have no limitation for a given use. Limitation that do not } \\
\text { reduce Appreciable the productivity and benefit. No need for a } \\
\text { high level of input. }\end{array}$ \\
\hline S2 & $\begin{array}{l}\text { Moderately } \\
\text { suitable }\end{array}$ & $\begin{array}{l}\text {-Land having minor limitation that could reduce productivity or } \\
\text { benefits .Adaptive inputs are required to reach the same yield as } \\
\text { that of class s1 }\end{array}$ \\
\hline S3 & $\begin{array}{l}\text { Marginal } \\
\text { Suitable }\end{array}$ & $\begin{array}{l}\text {-Having moderate limitations for certain use, in which the amount } \\
\text { of surplus input is only marginally justified. }\end{array}$ \\
\hline N1 & Not Suitable & $\begin{array}{l}\text {-Land with severe limitations for the land use under consideration. } \\
\text { Major factors of the earth soil, Climate, LGP and topography. }\end{array}$ \\
\hline
\end{tabular}

Source: Field Work, 2018

Table 4 : Saaty scale of rating influence of factors

\begin{tabular}{|l|l|l|l|}
\hline No & $\begin{array}{l}\text { Intensity of } \\
\text { influence }\end{array}$ & Definition & Explanation \\
\hline $\mathbf{1}$ & $\mathbf{1}$ & Equal importance & Two factors influence equally to objective \\
\hline $\mathbf{2}$ & $\mathbf{3}$ & $\begin{array}{l}\text { Somewhat more } \\
\text { important }\end{array}$ & Experience and judgment slightly one over the other \\
\hline $\mathbf{3}$ & $\mathbf{5}$ & Much more important & Experience and judgment strongly favor one over the other \\
\hline $\mathbf{4}$ & $\mathbf{7}$ & $\begin{array}{l}\text { Very much more } \\
\text { important }\end{array}$ & $\begin{array}{l}\text { Experience and judgment are very strongly to favor one } \\
\text { over the other. Its importance is demonstrated in practice. }\end{array}$ \\
\hline $\mathbf{5}$ & $\mathbf{9}$ & $\begin{array}{l}\text { Absolutely more } \\
\text { important }\end{array}$ & $\begin{array}{l}\text { The evidence favoring one over the other is of highest } \\
\text { possible validity }\end{array}$ \\
\hline $\mathbf{6}$ & $\mathbf{2 , 4 , 6 , 8}$ & Intermediate values & When compromise is needed \\
\hline
\end{tabular}

Source: Field Work, 2018

TABle 5: ANAlytical HiERARChy Process (AHP) DERIVATION

\begin{tabular}{|l|l|l|l|l|l|l|l|l|l|l|l|}
\hline Criteria & Elevation & Slope & LULC & $\begin{array}{l}\text { Rain } \\
\text { fall }\end{array}$ & $\begin{array}{l}\text { Tempe } \\
\text { rature }\end{array}$ & LGP & $\begin{array}{l}\text { Soil } \\
\text { textur } \\
\mathrm{e}\end{array}$ & $\begin{array}{l}\text { Soil } \\
\text { drainag } \\
\mathrm{e}\end{array}$ & $\begin{array}{l}\text { Soil } \\
\text { dept } \\
\mathrm{h}\end{array}$ & $\begin{array}{l}\text { Soil } \\
\text { PH }\end{array}$ & $\begin{array}{l}\text { Soi } \\
\text { l } \\
\text { OC }\end{array}$ \\
\hline Elevation & 1 & $5 / 1$ & $3 / 1$ & $3 / 1$ & 3 & $1 / 3$ & $3 / 1$ & $7 / 1$ & $1 / 9$ & $1 / 3$ & $1 / 3$ \\
\hline Slope & $1 / 5$ & 1 & $1 / 7$ & $1 / 7$ & $1 / 5$ & $1 / 7$ & 3 & $1 / 3$ & 1 & $1 / 3$ & $1 / 7$ \\
\hline LULC & $3 / 3$ & $1 / 7$ & 1 & 5 & $1 / 1$ & $1 / 5$ & $7 / 1$ & $1 / 3$ & $1 / 7$ & $1 / 5$ & $7 / 1$ \\
\hline Rainfall & $3 / 1$ & 1 & $1 / 3$ & 1 & $1 / 3$ & $1 / 3$ & 1 & 1 & 1 & 1 & $1 / 3$ \\
\hline Temperate & $1 / 7$ & $3 / 1 /$ & 1 & $1 / 1$ & 1 & 3 & $1 / 7$ & $1 / 5$ & $1 / 7$ & $1 / 7$ & $1 / 3$ \\
\hline LGP & $1 / 3$ & $1 / 7$ & $1 / 5$ & $1 / 7$ & $1 / 3$ & 1 & $1 / 7$ & $5 / 1$ & $1 / 5$ & $1 / 3$ & $1 / 9$ \\
\hline Soil texture & $1 / 3$ & $1 / 3$ & $1 / 5$ & 1 & 1 & $1 / 7$ & 1 & $1 / 7$ & 1 & $1 / 5$ & $1 / 7$ \\
\hline Soil drain & $1 / 7$ & $1 / 3$ & $1 / 7$ & $1 / 3$ & 1 & $1 / 7$ & $1 / 3$ & 1 & $1 / 3$ & $1 / 3$ & $9 / 1$ \\
\hline
\end{tabular}


Page $\mathbf{8}$ of $\mathbf{2 3}$

\begin{tabular}{|l|l|l|l|l|l|l|l|l|l|l|l|}
\hline Soil depth & $9 / 1$ & $1 / 7$ & $7 / 1$ & $1 / 3$ & $7 / 1$ & $1 / 7$ & $1 / 3$ & $5 / 1$ & 1 & $5 / 1$ & $1 / 7$ \\
\hline Soil PH & $3 / 1$ & $1 / 3$ & $1 / 7$ & $1 / 3$ & $1 / 5$ & $1 / 3$ & $1 / 5$ & $1 / 3$ & $1 / 7$ & 1 & $1 / 3$ \\
\hline Soil OC & $1 / 7$ & $1 / 3$ & $1 / 7$ & $1 / 7$ & $1 / 3$ & $1 / 7$ & $1 / 3$ & $1 / 9$ & $1 / 5$ & $1 / 7$ & $1 / 7$ \\
\hline Sum & 13.61 & 16.74 & 13.29 & 12.41 & 15.39 & 5.89 & 16.58 & 20.44 & 5.35 & 15.67 & 9.1 \\
\hline
\end{tabular}

Source: Field Work, 2018

TABLE 6 : EIGEN VECTOR WEIGHT

\begin{tabular}{|l|l|l|l|}
\hline Criteria & Weight & \% influence & Rating \\
\hline Elevation & 0.07 & 0.03 & 3 \\
\hline Slope & 0.16 & 0.025 & 4 \\
\hline LULC & 0.13 & 0.01 & 11 \\
\hline Rainfall & 0.05 & 0.054 & 1 \\
\hline Temperature & 0.04 & 0.04 & 2 \\
\hline LGP & 0.02 & 0.121 & 10 \\
\hline soil Texture & 0.03 & 0.015 & 8 \\
\hline Soil Drainage & O.25 & 0.013 & 9 \\
\hline Soil depth & 0.05 & 0.021 & 7 \\
\hline Soil PH & 0.15 & 0.023 & 5 \\
\hline Soil OC & 0.34 & 0.022 & 6 \\
\hline
\end{tabular}

Source: Field Work, 2018

\subsection{Land Suitability Analysis}

\subsubsection{Factors of Suitability for Agricultural Crops}

The slope map generated for the evaluation study has an immense influence on work efficiency, erosion control practices and crop adaptability. Rainfall being the only source of water for Rain Fed Agriculture, its distribution and dependability plays a significant role in optimizing crop production.

\subsubsection{Topography as a parameter}

FIGURE 5 : ELEVATION A AND SUITABILITY MAP OF TEFF
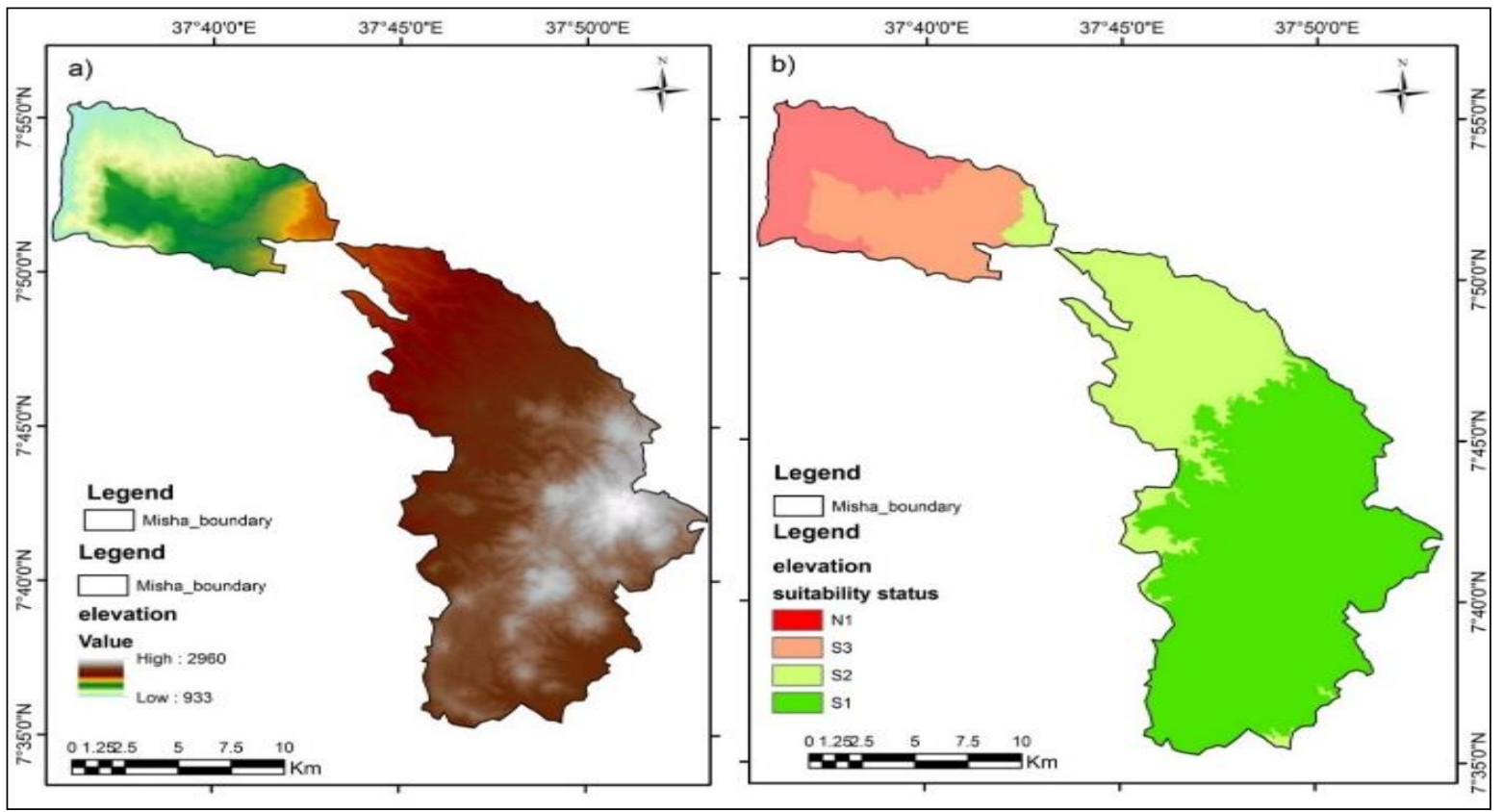

Figure 6 : Elevation And Suitability MaP OF BARLey In The Study Area

Source: Field Work, 2018 
Page 9 of 23

Figure 7: SLOPE AND SUITABILITY MAP OF SLOPE FOR TEFF AND BARLEY IN THE STUDY AREASOURCE: FIELD WORK, 2018

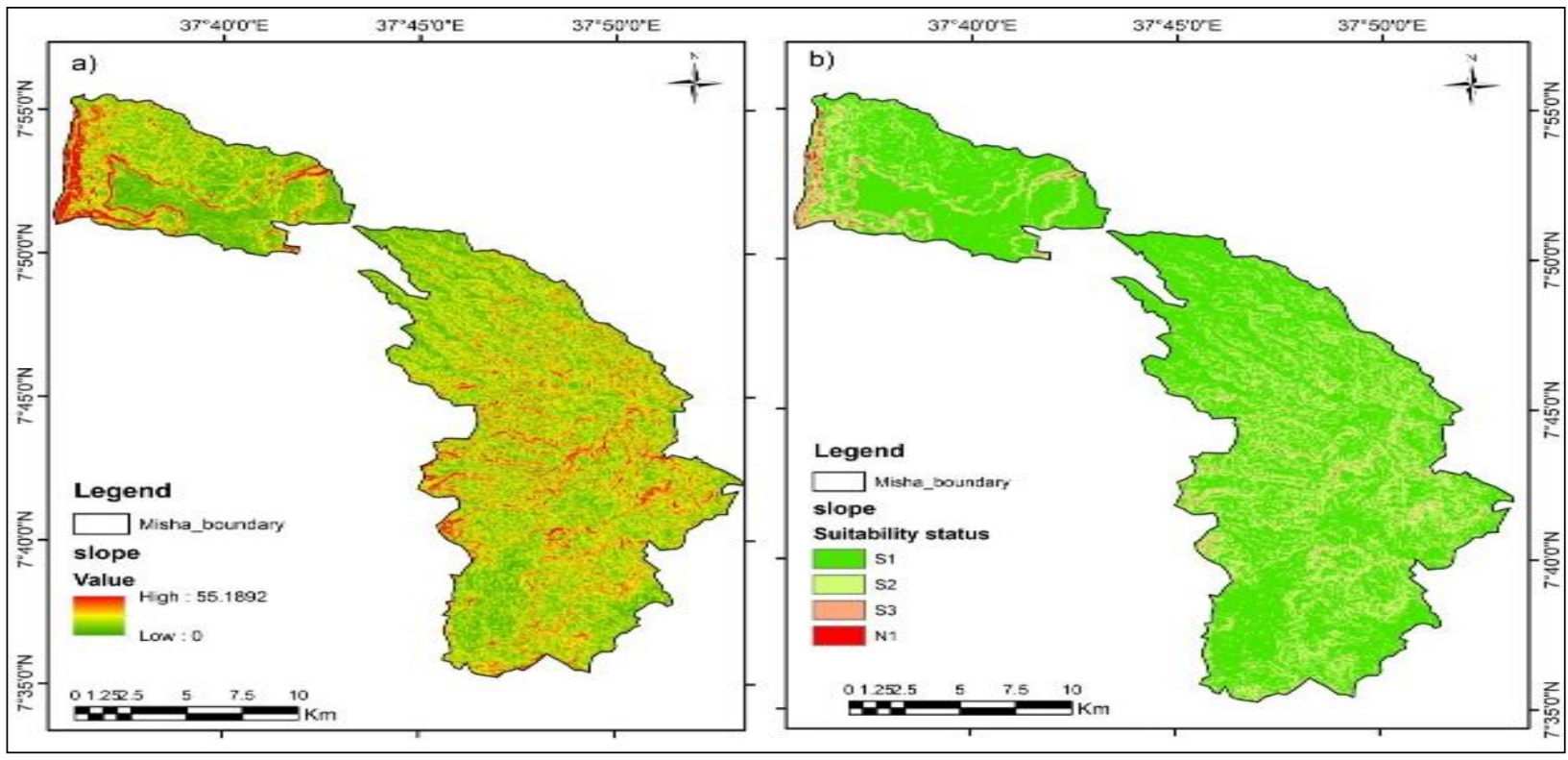

Figure 8: SLOPE AND SUITABILITy MAP OF Slope For TEFF AND BARLEy IN THE STUdy AREA

SOURCE: FIELD WORK, 2018

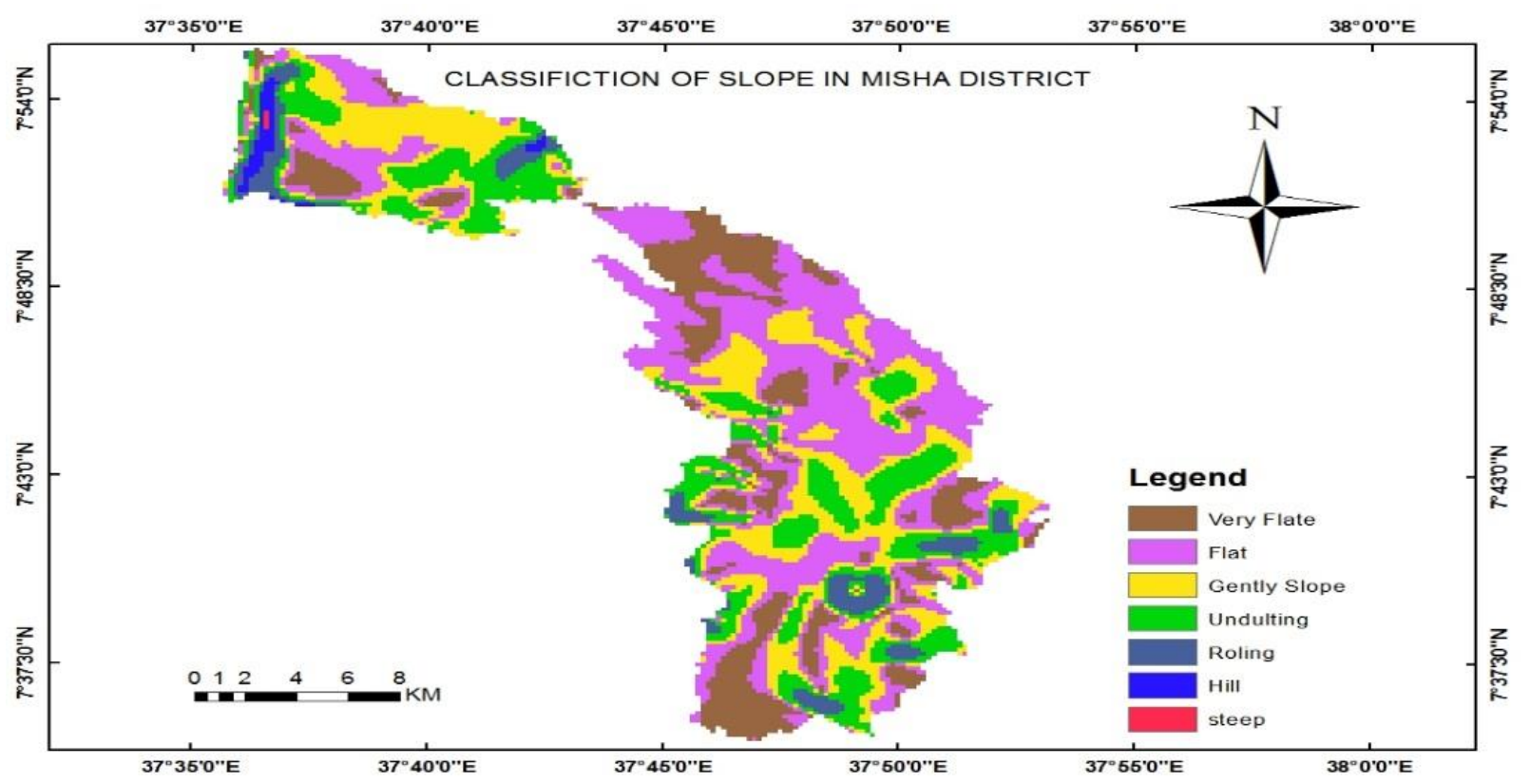

TABlE 7 : CLASSIFICATION OF SLOPE

SOURCE: FIELD WORK, 2018

\begin{tabular}{|l|l|l|l|l|l|l|}
\hline Very flat & Flat & Gently slop & Undulating & Rolling & Hilly & Steep \\
\hline $0-0.5$ & $0.5-2$ & $2-5$ & $5-8$ & $8-16$ & $16-30$ & $>30$ \\
\hline
\end{tabular}

Source: Field Work, 2018 
Slope is a measure of terrain steepness; it is the degree to which land is not horizontal. Slope has an impact on the agricultural suitability of an area: areas with steep slopes are more difficult to cultivate and are more likely to lose soil and nutrients through erosion. Slope is measured in percent rise. A zero slope indicates flat ground while a slope of $100 \%$ is equivalent to a $45^{\circ}$ angle.ASTER satellite image was used to derive slope map of the study area. And then the slope map was reclassified to achieve the required slope status. The slope map was reclassified to suitability classes according to Global Agro Ecological Zone (2012).

\subsubsection{Climate as a parameter}

\section{TABLE 8 : RAINFALL AND SUITABILITY MAP OF RAINFALL FOR TEFF IN THE STUDY AREA}

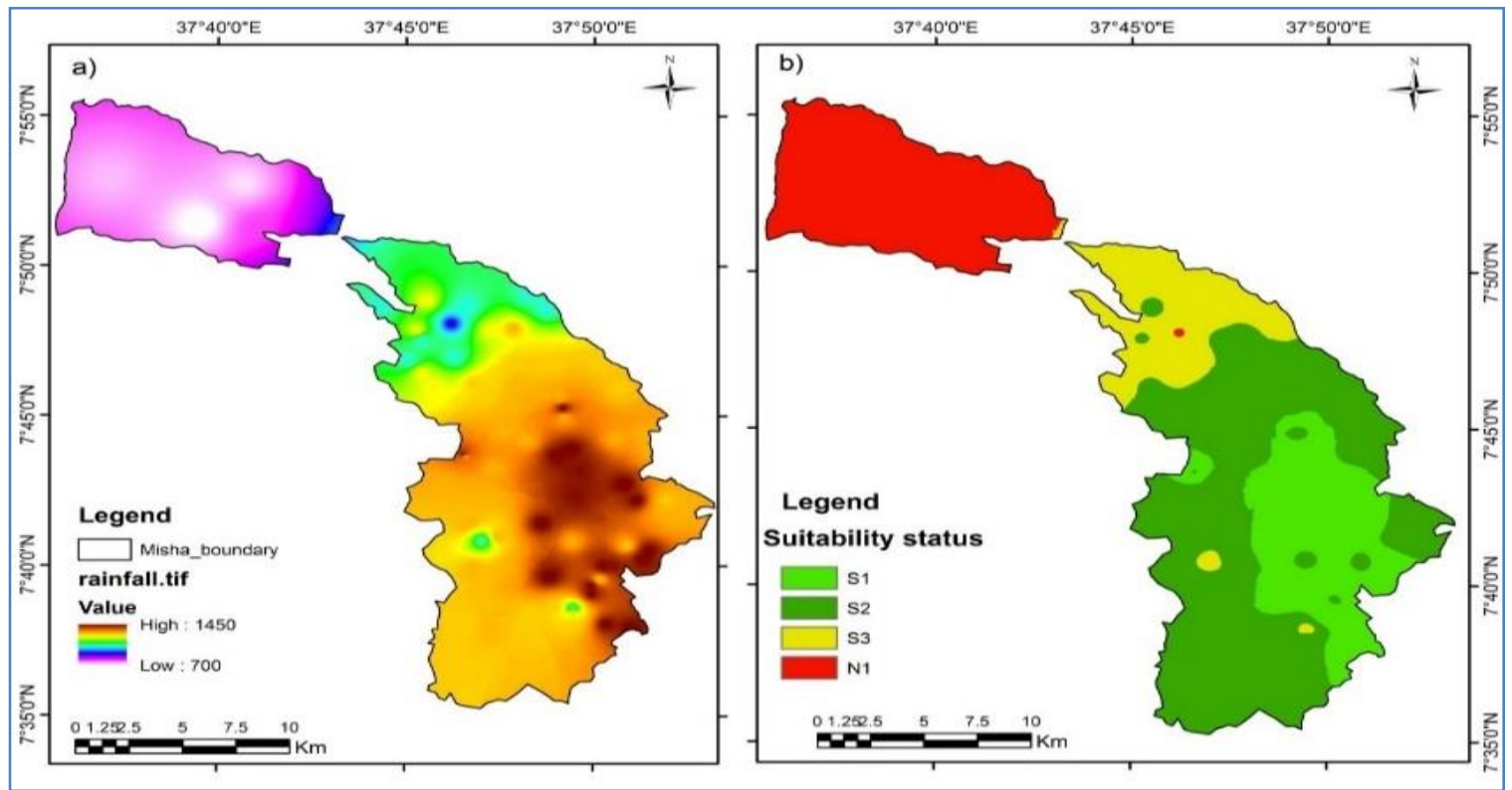

Source: Field Work, 2018

FIGURE 9 RAINFALL A) AND SUITABILITY MAP OF RAINFALL FOR TEFF IN THE STUDY AREA

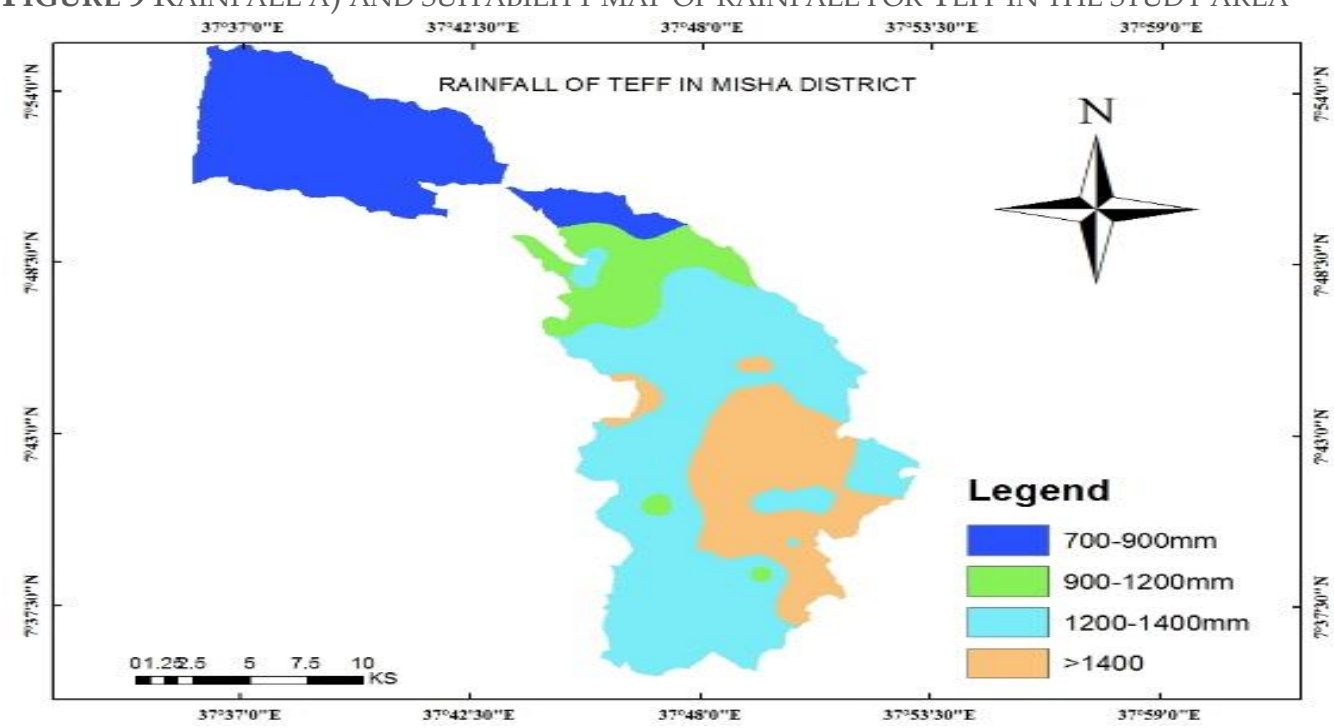

SOURCE: FIELD WORK, 2018

The suitability rainfall S1 (High suitable) (700-900mm), S2 (Moderately suitable) (900-1200), S3 (Marginal suitable) (1200-1400), and N1 (Not suitable) (>1400) rating scale 0f rainfall teff. 
Figure 10 Temperature a) and suitability map of temperature for Teff in the study area
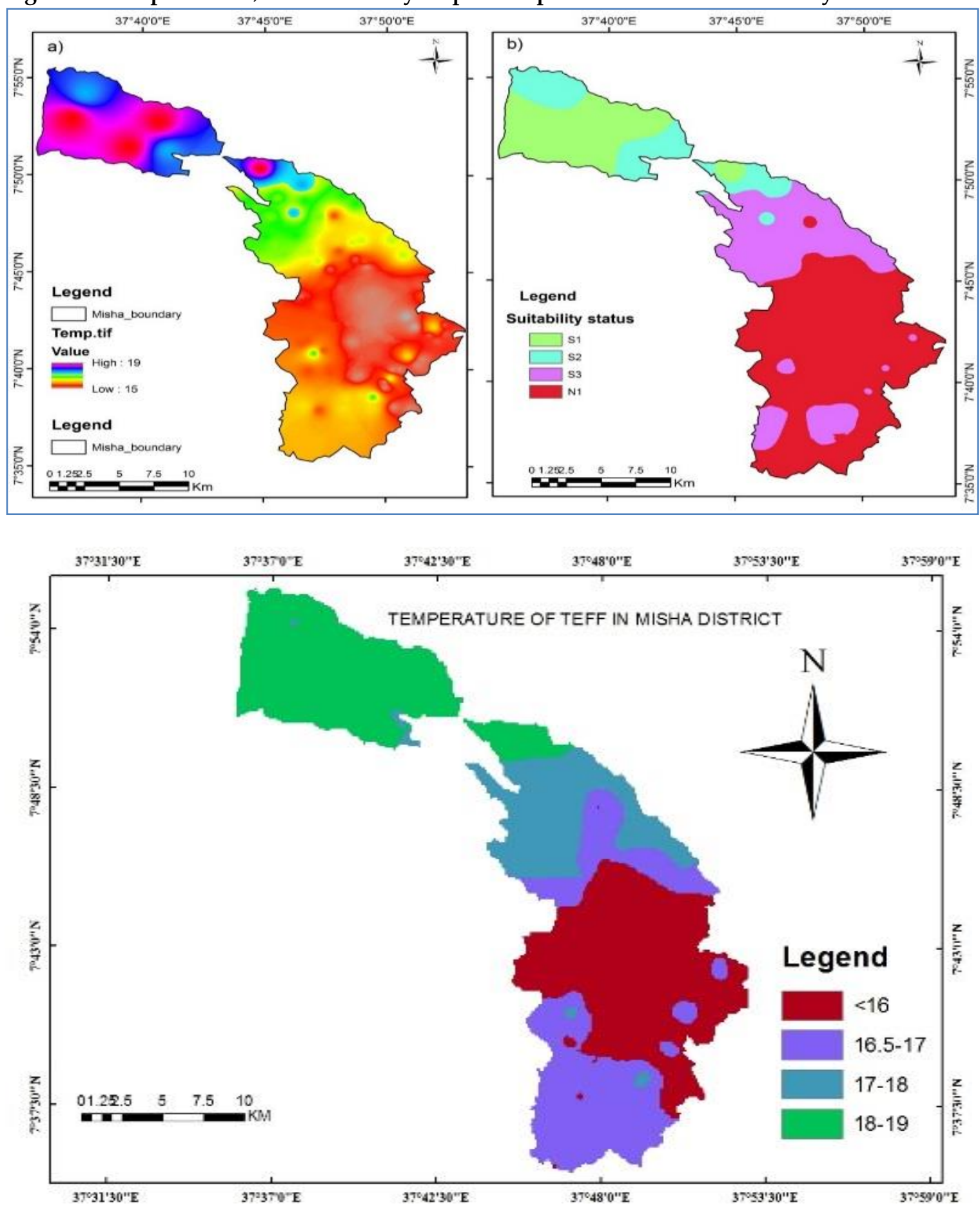

Source: Field Work, 2018

The above figure shows the suitability temperature S1 (High suitable (18-19), S2 (moderately suitable) (17-18), S3 (marginal suitable) (16.5-17), and N1 (not suitable) $(<16)$ rating scale 0f rainfall teff. the highest and lowest mean average rainfall and temperature distribution in teff cultivation in the study area. The place of high rain fall and low temperature occurs in Dega area and low rain fall and high temperature occurs in kola area of the study. Weinadega and kola area is high suitable for teff production than Dega area. 
Figure 11 Rainfall a) and suitability map of rainfall for Barley in the study area
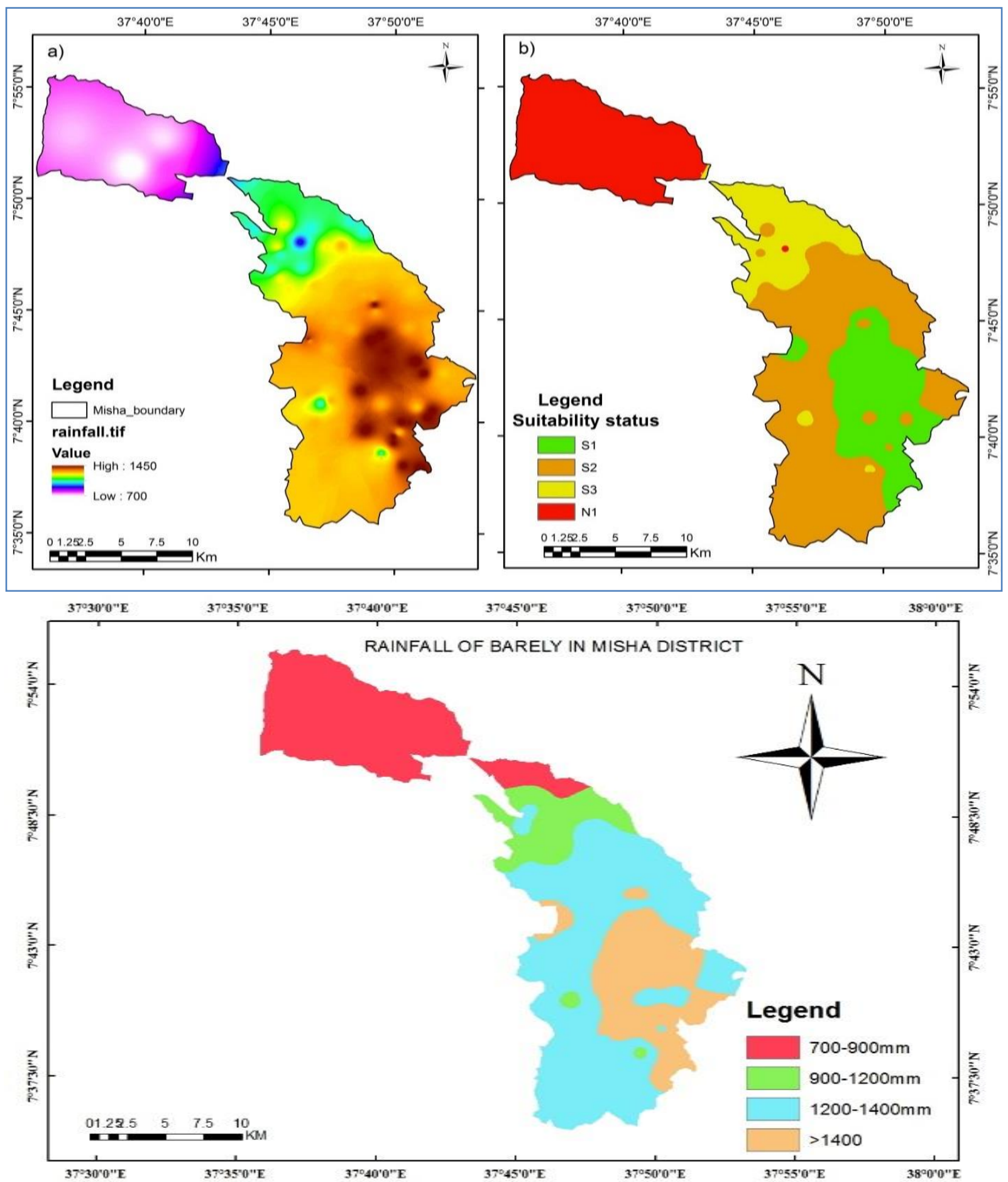

Source: Field Work, 2018

The suitability rainfall S1 (>1400mm), S2 (1200-1400), S3 (900-1200), and N1 (700-900) rating scale 0f rainfall Barley. 
Page 13 of 23

Figure 12 Temperature a) and suitability map of temperature for Barley in the study area
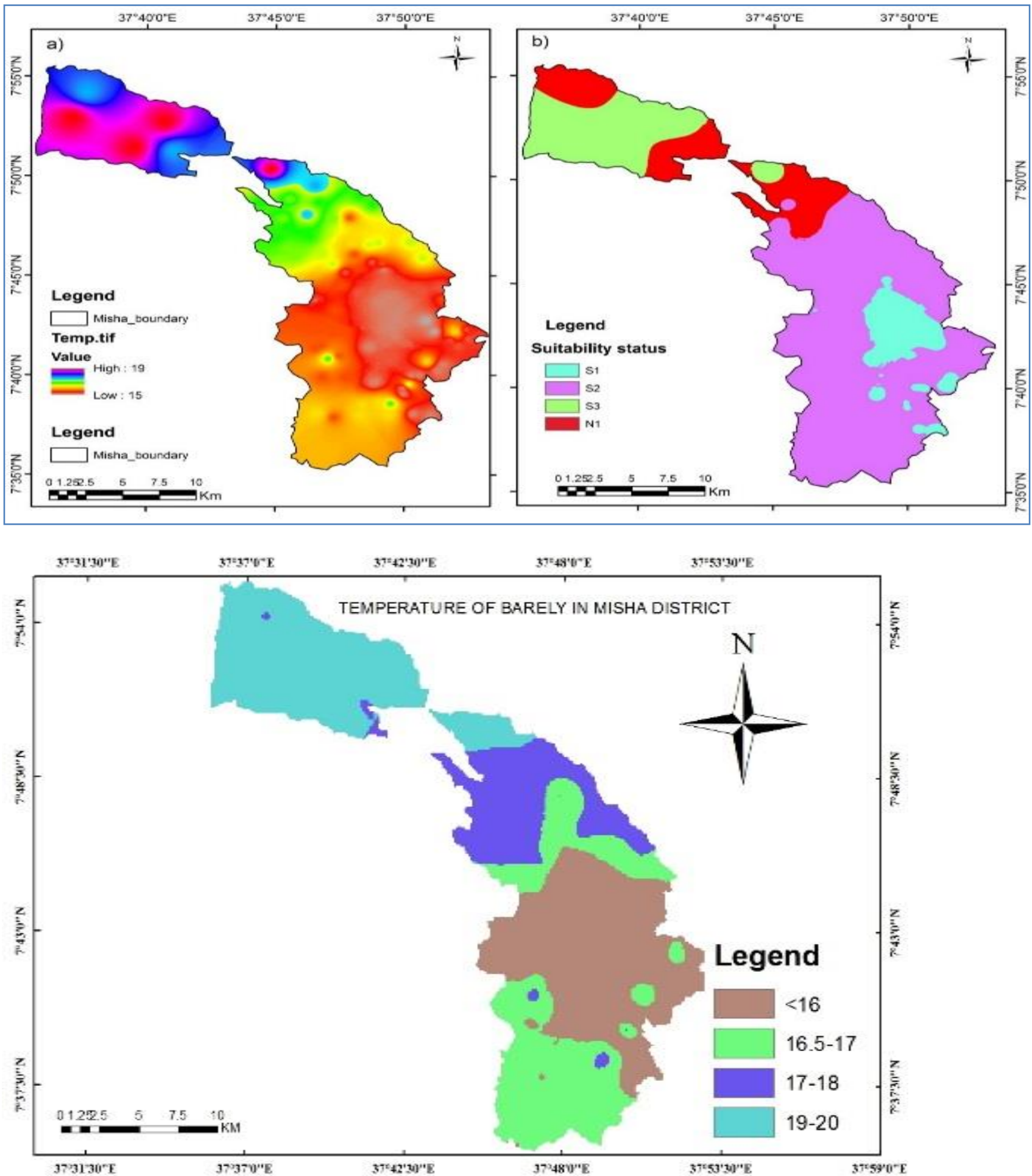

Source: Field Work, 2018

Th above figure shows the suitability temperature S1 (High suitable $(<16)$, S2 (moderately suitable) (16.5-17), S3 (marginal suitable) (17-18), and N1 (not suitable) (19-20) rating scale of rainfall Barley. the highest and lowest mean average rain fall and temperature distribution in barley cultivation in the study area. The place of high rain fall and low temperature occurs in Dega area and low rain fall and high temperature occurs in kola area of the study. Dega area is high suitable for barley production than kola area. 
Figure 13 Length of growing period (LGP) a) LGP suitability map for Teff and Barley in the study area

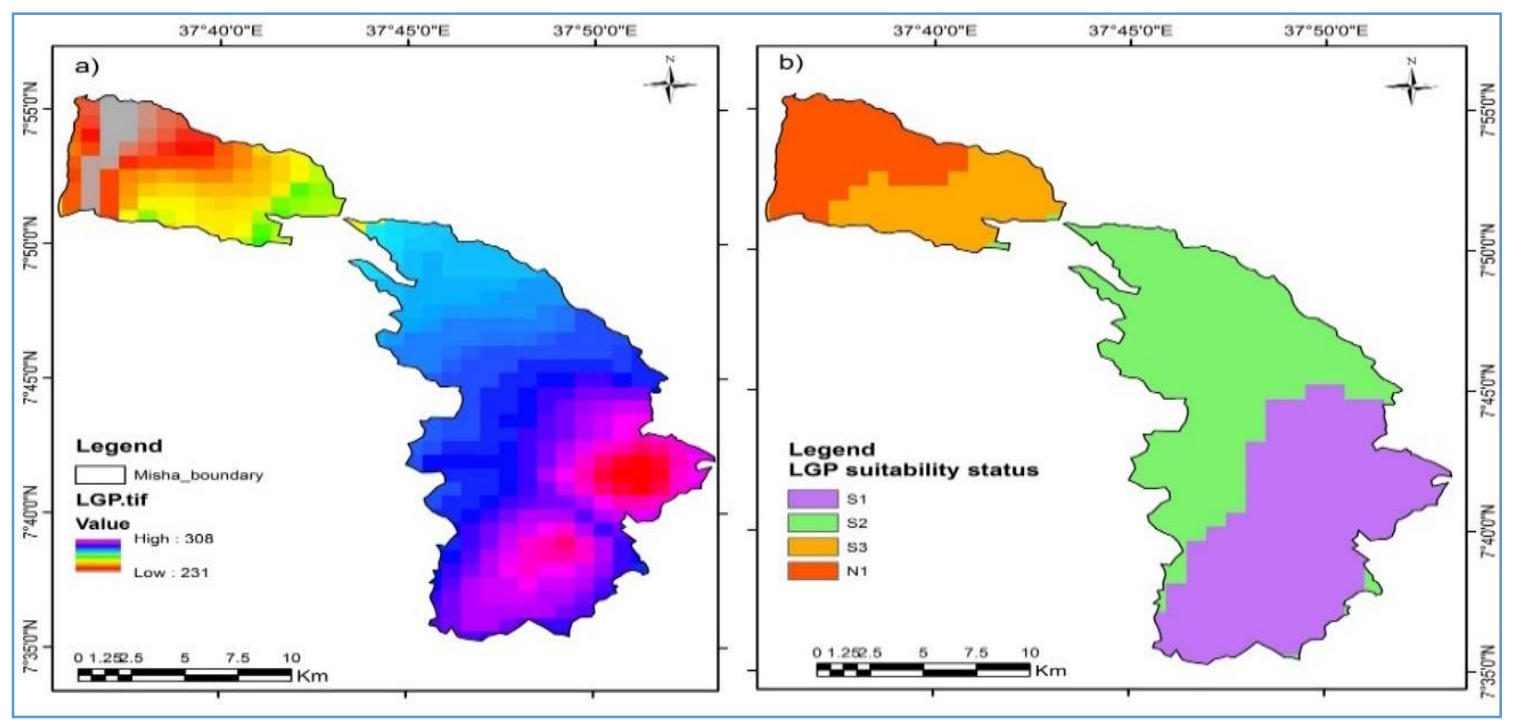

Source: Field Work, 2018

The length of growing period (LGP) generally refers to the cumulative amount of time during a normal year when moisture conditions are adequate for plant growth. Here, LGP is based on the number of days with a mean daily temperature above $5^{\circ} \mathrm{C}$ and with available water (from precipitation or stored soil moisture) exceeding half the potential evapotranspiration. LGP captures multiple factors (rainfall, potential evapotranspiration, and soil moisture storage properties) that together define the most important dimensions of agricultural potential. Thus a longer LGP generally indicates higher agricultural potential. Even within areas with long growing periods, other characteristics - such as steep hillsides or nutrient-poor soils - may limit agricultural production. Misha District has good LGP, for crop production given other factors are constant.

\subsubsection{Physicho-chemical and biological Soil as a parameter}

Figure 14 Soil texture a) suitability map for Teff in the study area

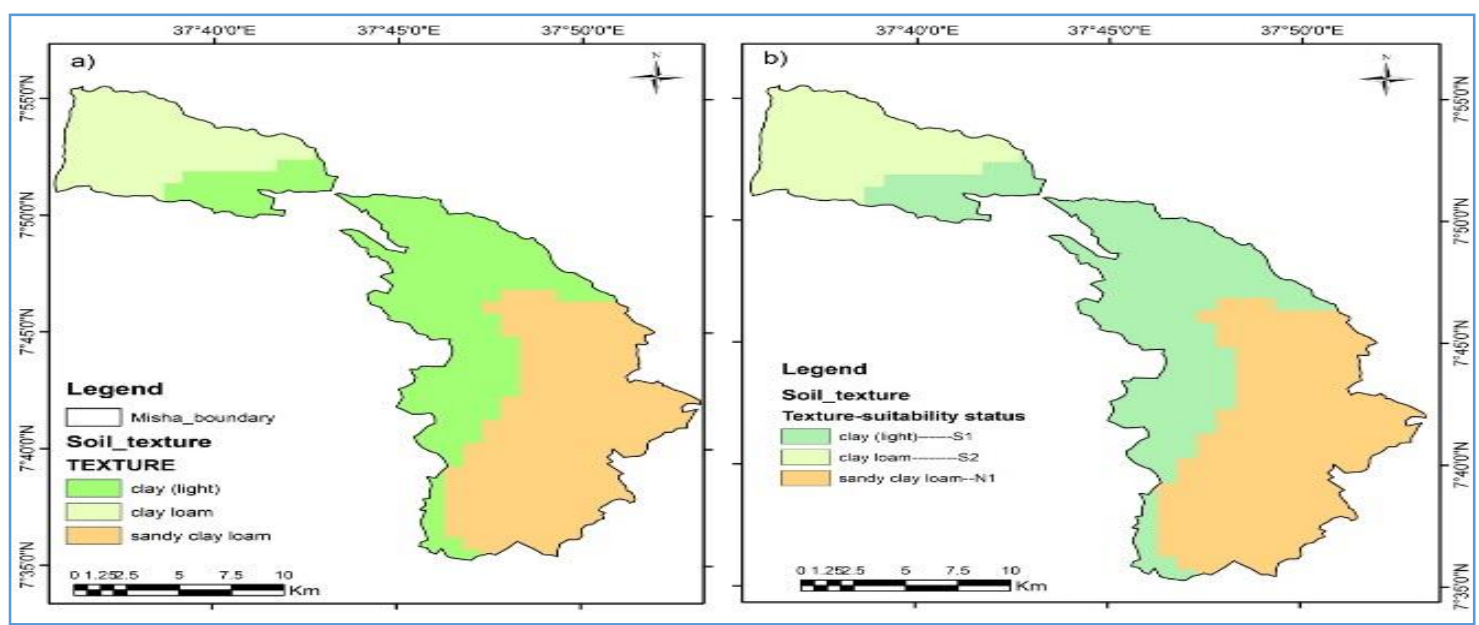

Source: Field Work, 2018 
Figure 15 Soil texture a) suitability map for Barley in the study area

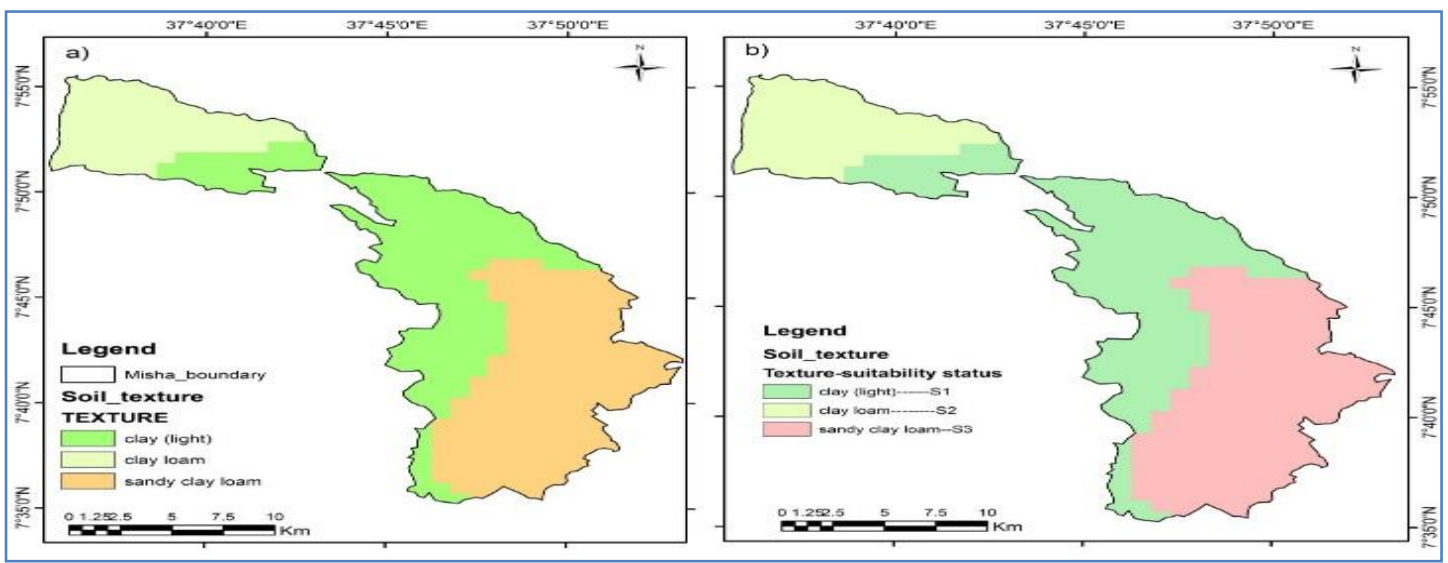

Source: Field Work, 2018

Texture classes reflect the relative proportion of clay, silt, and sand in the soil. Textural classes in combination with other properties, it is directly related to soil structures, consistency, porosity and caption exchange capacity. The texture of the upper $30 \mathrm{~cm}$ of the soil, which are important for tillage and water retention.

Figure 16 Soil drainage a) suitability map for Teff in the study area

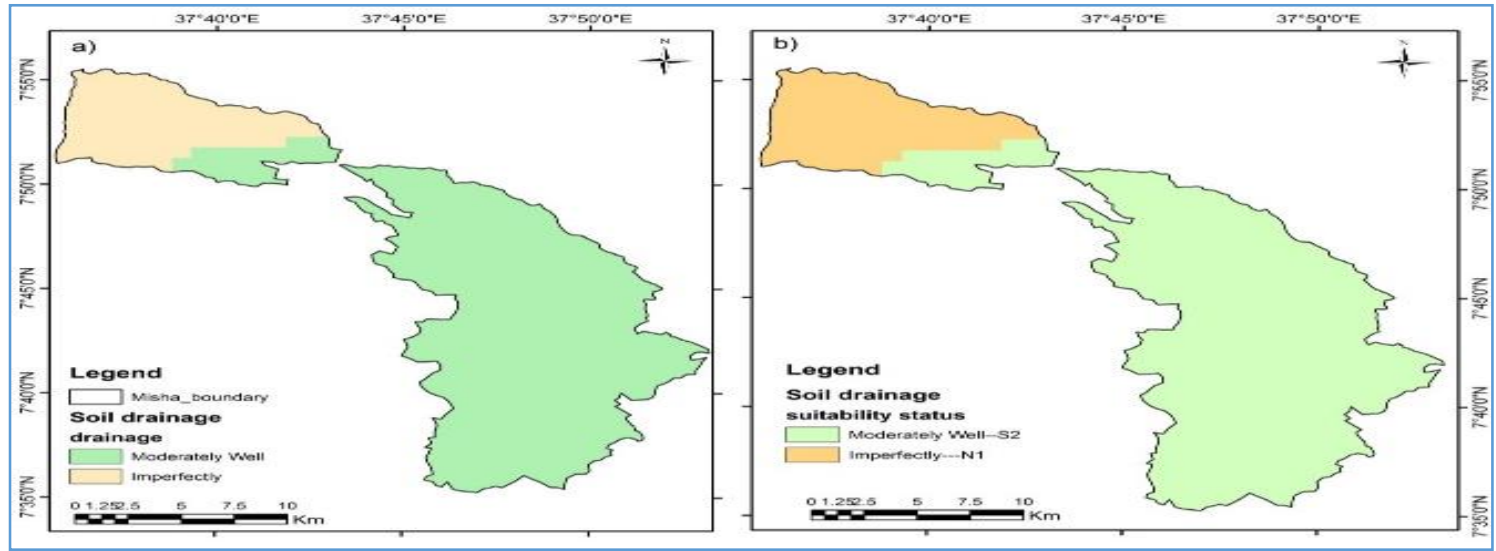

Source: Field Work, 2018

Figure 17 Soil drainage a) suitability map for Barley in the study area

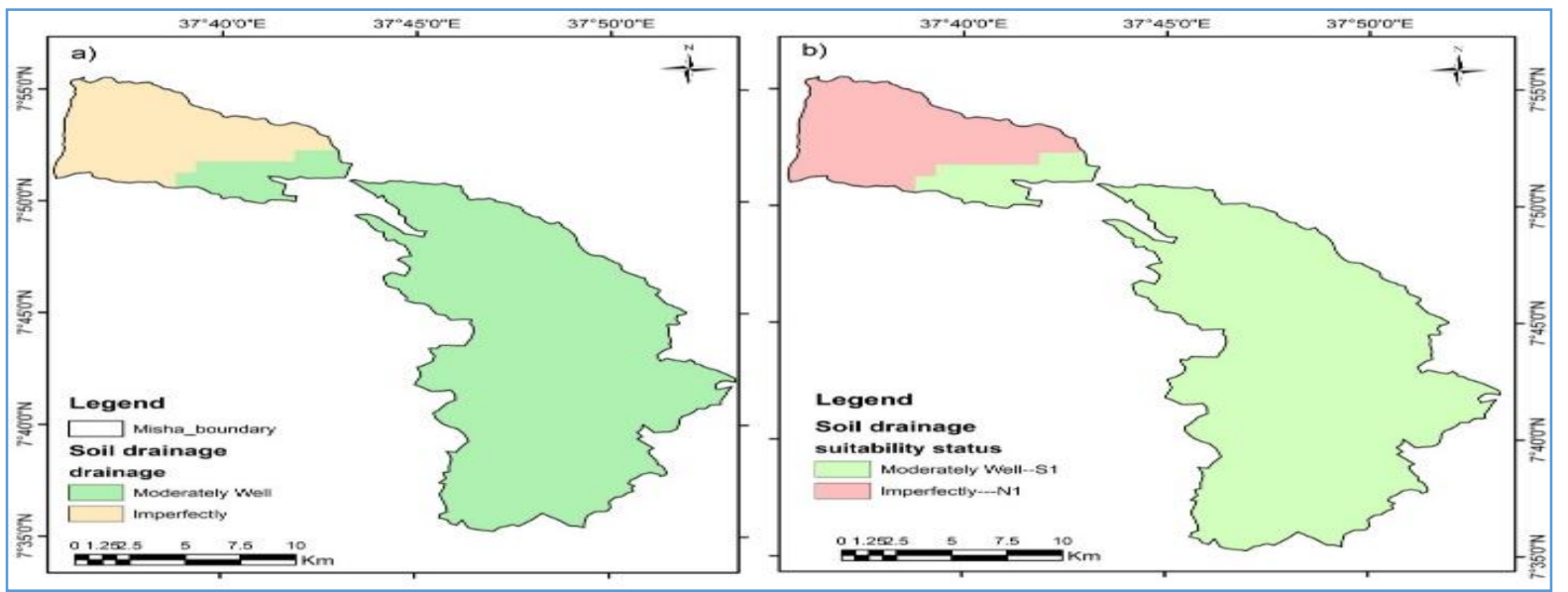

Source: Field Work, 2018 
Drainage is one of the important physical characteristics of soils. Well drained soils are good for agriculture and other plant growth in general. Drainage is influenced by soil texture, soil type and soil depth. Drainage in turn affects soil moistures and, which affects plant growth.

Figure 18 Soil depth a) suitability map for Teff in the study area

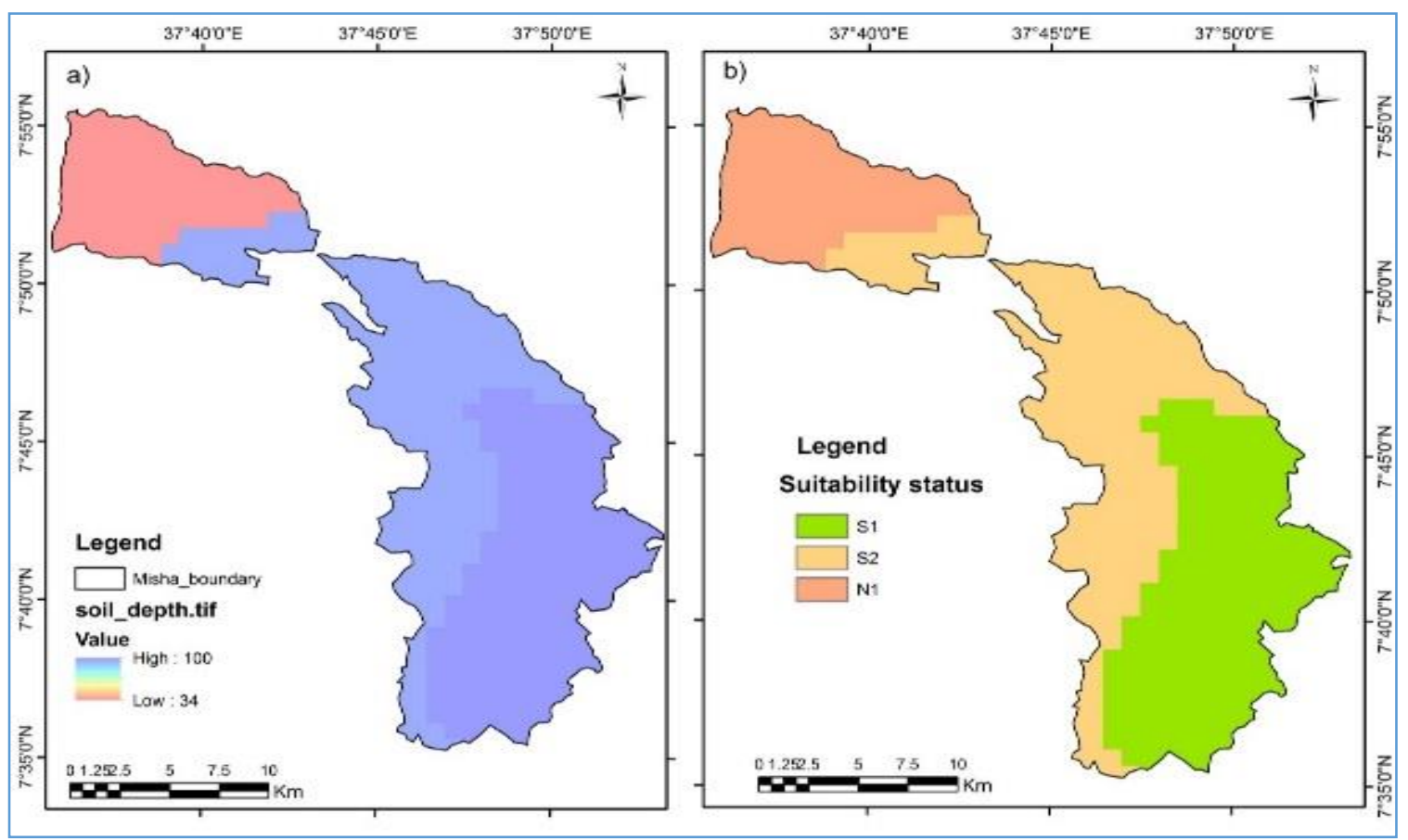

Source: Field Work, 2018

Figure 19 Soil depth a) Soil suitability depth map for Barley in the study area

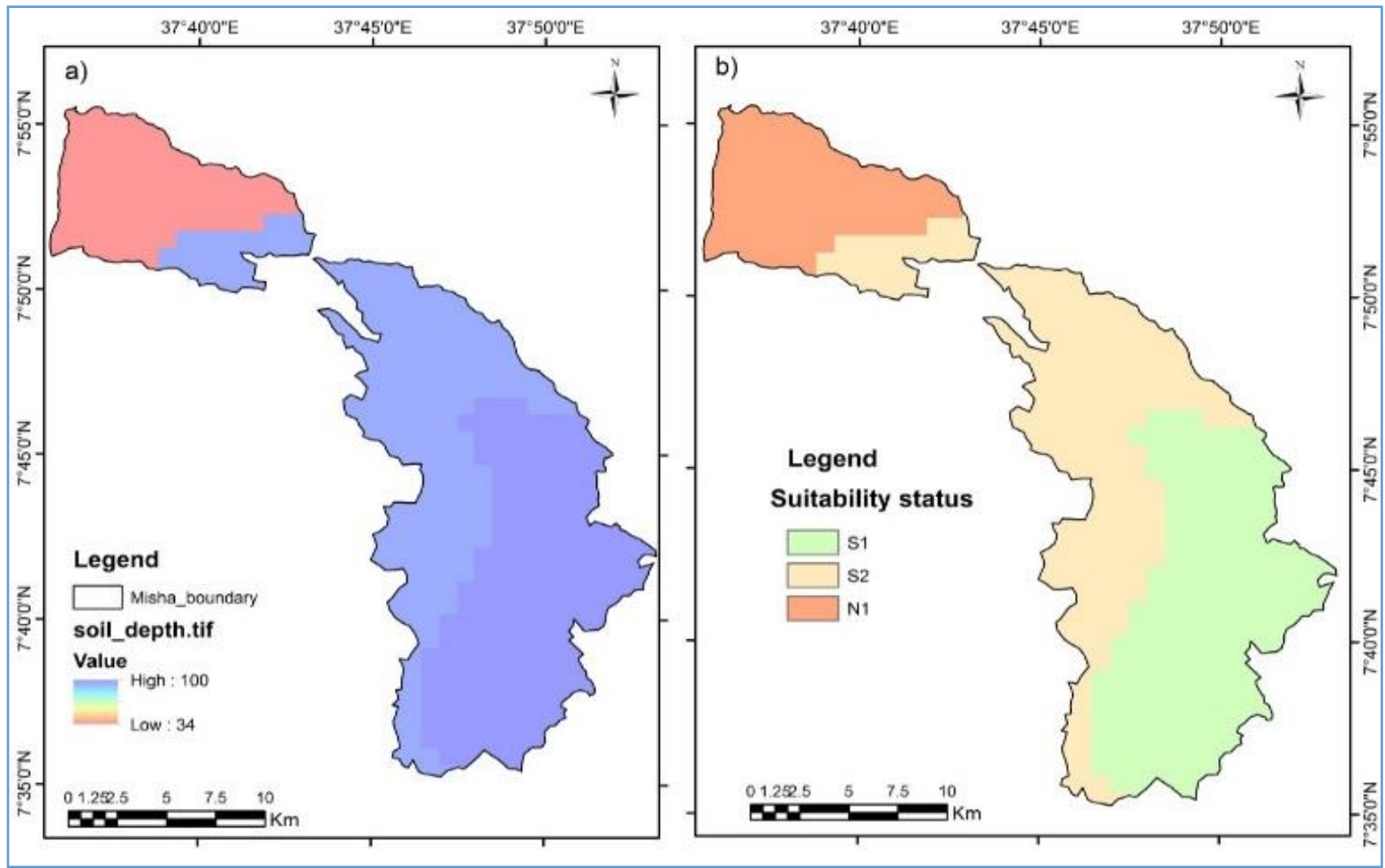

Source: Field Work, 2018 
Figure 20 Soil PH a) suitability map for Teff and Barley in the study area

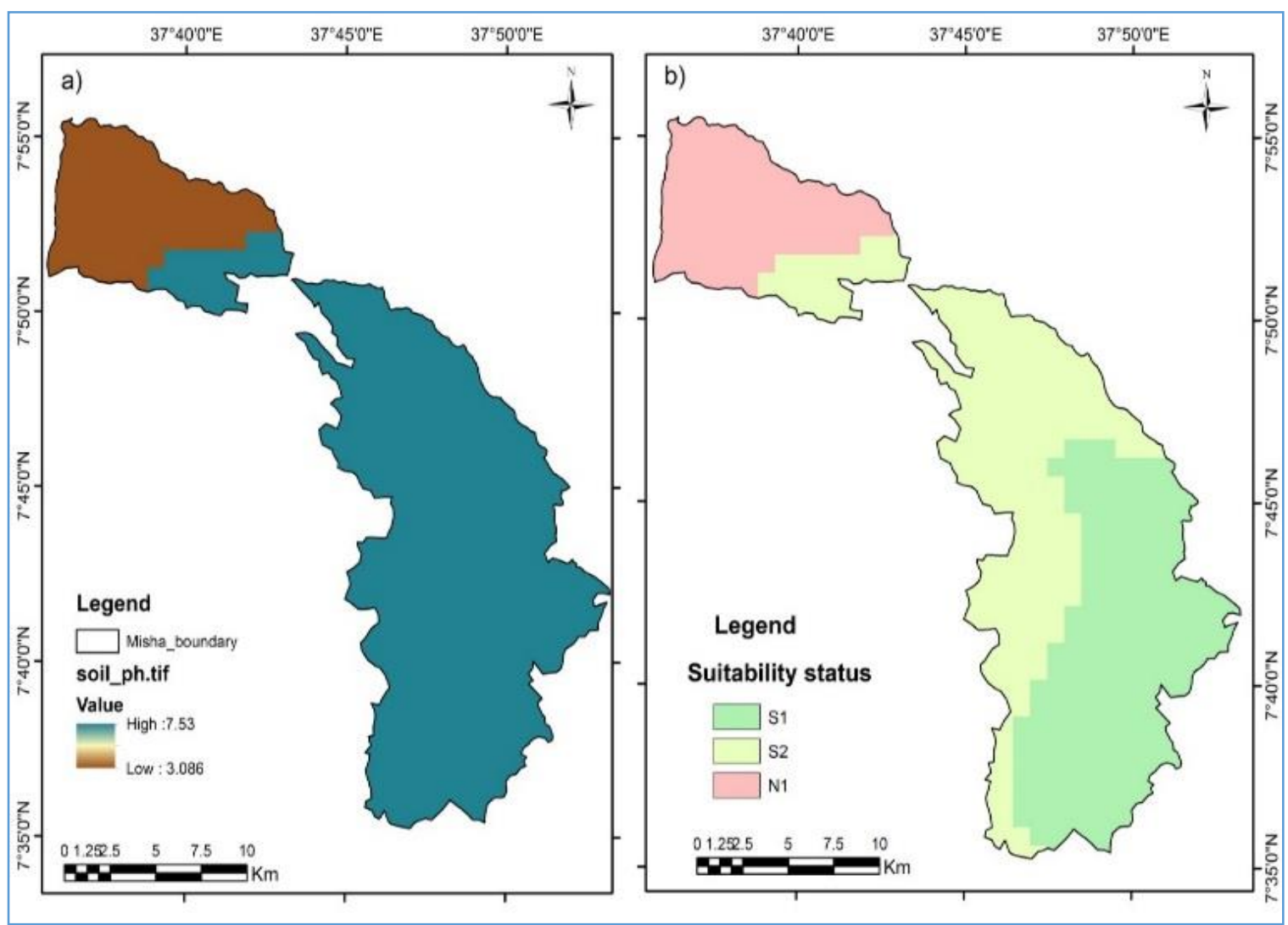

Source: Field Work, 2018

Figure 21 Soil OC a) suitability map for Teff and Barley in the study area

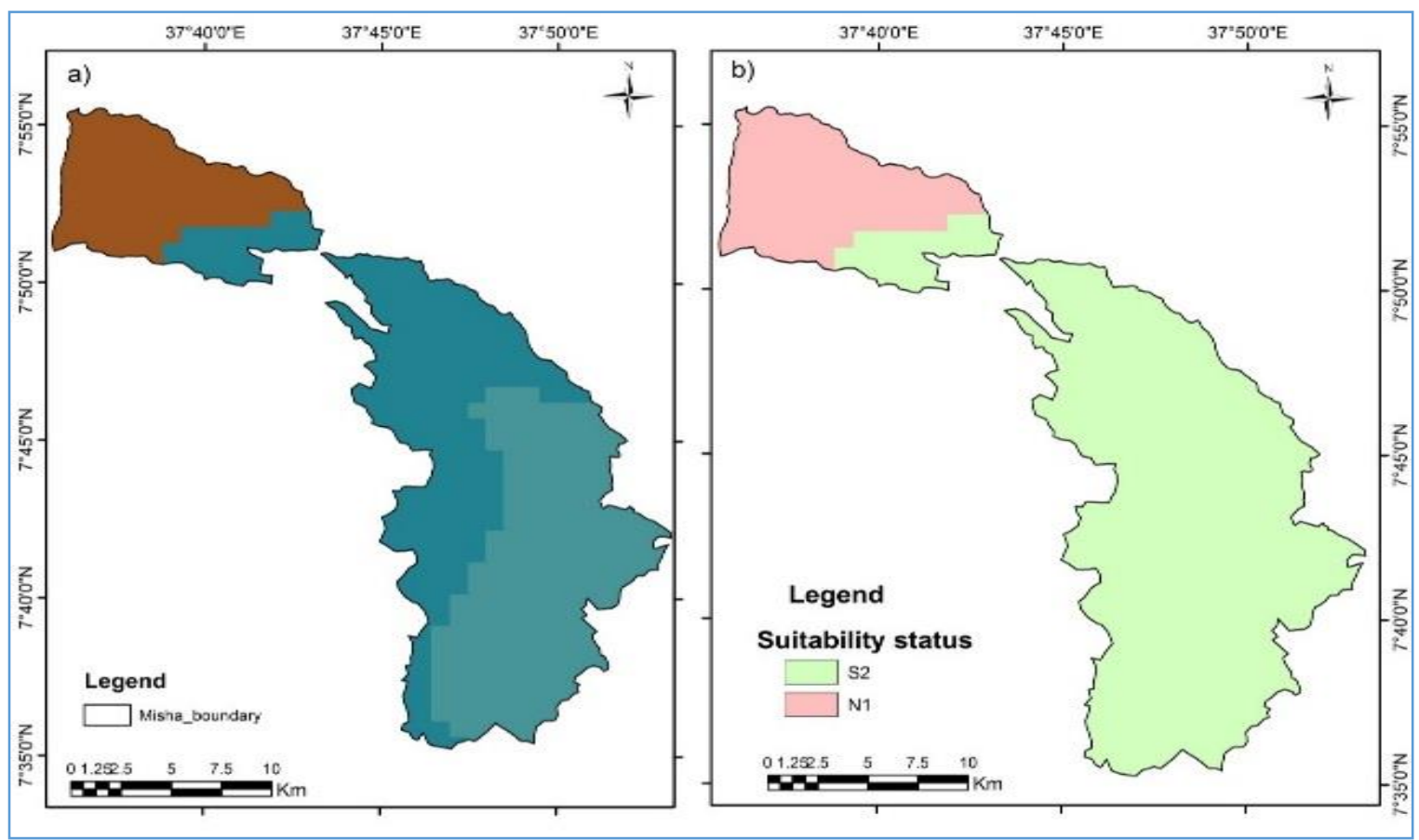

Source: Field Work, 2018 
Page 18 of $\mathbf{2 3}$

Criteria considered for major cereal crops suitability analysis (experts' knowledge) Table 9 Environmental requirements rating and influence for Teff in the study area

\begin{tabular}{|c|c|c|c|c|c|c|c|}
\hline \multicolumn{2}{|c|}{ Factor map } & \multirow{2}{*}{$\begin{array}{l}\text { S1 } \\
1800-2800\end{array}$} & \multirow{2}{*}{$\begin{array}{l}\text { S2 } \\
2800- \\
2960\end{array}$} & \multirow{2}{*}{$\begin{array}{l}\text { S3 } \\
900- \\
1400\end{array}$} & \multirow{2}{*}{$\begin{array}{l}\mathbf{N 1} \\
<900\end{array}$} & \multirow{3}{*}{$\begin{array}{c}\text { Total } \\
36298\end{array}$} & \multirow{4}{*}{$\frac{\text { Influence (\%) }}{19}$} \\
\hline \multirow{9}{*}{ 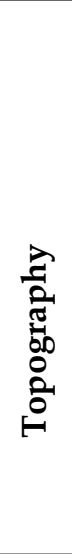 } & \multirow{3}{*}{$\begin{array}{l}\text { Elevation (m) } \\
\text { Area (ha) } \\
\text { Area (\%) }\end{array}$} & & & & & & \\
\hline & & 27539.28 & 4426.2 & 4332.43 & 0.09 & & \\
\hline & & 75.87 & 12.19 & 11.94 & 0.017 & 100 & \\
\hline & \multirow{3}{*}{$\begin{array}{l}\text { Slope }(\%) \\
\text { Area (ha) }\end{array}$} & $0-13$ & $13-25$ & $25-40$ & $>40$ & \multirow[t]{2}{*}{36298} & \multirow[t]{3}{*}{7} \\
\hline & & 24752.8 & 10129.68 & 1333.08 & 82.44 & & \\
\hline & & 68.19 & 27.91 & 3.67 & 0.23 & 100 & \\
\hline & \multirow{3}{*}{$\begin{array}{l}\text { LULC(Type) Area(ha) } \\
\text { Area (\%) }\end{array}$} & $\mathrm{AL}$ & OSL & WL & $\mathrm{F}$ & \multirow[t]{2}{*}{36298} & \multirow[t]{3}{*}{13} \\
\hline & & 26755.55 & 9184.05 & 138.3 & 9184.05 & & \\
\hline & & 73.71 & 25.30 & 0.38 & 0.61 & 100 & \\
\hline \multirow{9}{*}{ 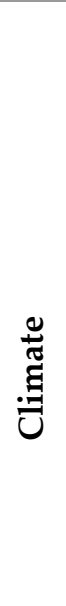 } & \multirow{3}{*}{$\begin{array}{l}\text { Rainfall (mm) } \\
\text { Area (ha) } \\
\text { Area (\%) }\end{array}$} & $1100-1450$ & $\begin{array}{l}900- \\
1100\end{array}$ & $700-900$ & $<700$ & \multirow[t]{2}{*}{36298} & \multirow[t]{3}{*}{23} \\
\hline & & 6972.66 & 15785.28 & 4778.11 & 8761.95 & & \\
\hline & & 19.21 & 43.49 & 13.16 & 24.14 & 100 & \\
\hline & \multirow{3}{*}{$\begin{array}{l}\text { Temperature }\left({ }^{\circ} \mathrm{C}\right) \\
\text { Area (ha) } \\
\text { Area (\%) }\end{array}$} & $15-17.5$ & $\begin{array}{l}17.5- \\
18.5\end{array}$ & $\begin{array}{l}18.5- \\
19.5\end{array}$ & $>20$ & \multirow[t]{2}{*}{36298} & \multirow[t]{3}{*}{11} \\
\hline & & 6076.44 & 4167.19 & 8600.49 & 17453.88 & & \\
\hline & & 16.74 & 11.48 & 23.69 & 48.08 & 100 & \\
\hline & \multirow{3}{*}{$\begin{array}{c}\text { LGP (days) } \\
\text { Area (ha) } \\
\text { Area }(\%)\end{array}$} & $270-308$ & $270-240$ & $240-220$ & $<220$ & \multirow[t]{2}{*}{36298} & \multirow[t]{3}{*}{4} \\
\hline & & 13333.14 & 14247.36 & 4106.25 & 4611.25 & & \\
\hline & & 36.73 & 39.25 & 11.31 & 12.70 & 100 & \\
\hline \multirow{15}{*}{ नं } & \multirow{3}{*}{$\begin{array}{c}\text { Soil texture (type) } \\
\text { Area (ha) } \\
\text { Area (\%) }\end{array}$} & Cli & $\mathrm{CL}$ & - & SCL & \multirow[t]{2}{*}{36298} & 9 \\
\hline & & 14447.91 & 6547.43 & & 15303.6 & & \\
\hline & & 39.08 & 18.04 & - & 18.78 & 100 & \\
\hline & Soil drainage(type) & - & MW & - & $\mathrm{I}$ & 36298 & 6 \\
\hline & Area (ha) & - & 29479.6 & - & 6818.4 & & \\
\hline & Area $(\%)$ & - & 81.22 & 18.78 & - & 100 & \\
\hline & Soil depth(cm) & $60-100$ & $50-60$ & $40-50$ & $<40$ & 36298 & 3 \\
\hline & Area (ha) & 14558.85 & 14921.01 & - & 6818.14 & & \\
\hline & Area (\%) & 40.11 & 41.11 & - & 18.78 & 100 & \\
\hline & Soil PH & $5.5-7.5$ & $4.5-5.5$ & $4.5-4$ & $<4$ & 36298 & 3 \\
\hline & Area (ha) & 14558.85 & 14921.01 & - & 6818.14 & & \\
\hline & Area (\%) & 40.11 & 41.11 & - & 18.78 & 100 & \\
\hline & Soil OC (\%) & - & $1.2-1.5$ & $0.8-1.2$ & $<1$ & 36298 & 2 \\
\hline & Area (ha) & - & 14921.01 & 14558.85 & 6818.14 & & \\
\hline & Area $(\%)$ & - & 41.11 & 40.11 & 18.78 & 100 & \\
\hline
\end{tabular}

Where $A L=$ agricultural land, $O S L=$ open shrub land, $F=$ forest, $W=$ wood land, and $C l i=$ clay light, $C L=c l a y$ loam, SCL= Sand clay loam, and $M W=$ moderately well; $I=$ imperfect

Source: Field Work, 2018 
Table 10 Environmental requirements rating and influence for Barley in the study area

\begin{tabular}{|c|c|c|c|c|c|c|c|}
\hline \multicolumn{2}{|c|}{ Factor map Scale } & \multirow{2}{*}{$\begin{array}{l}\text { S1 } \\
2600-2960\end{array}$} & \multirow{2}{*}{$\begin{array}{l}\text { S2 } \\
1800-2600\end{array}$} & \multirow{2}{*}{$\begin{array}{l}\text { S3 } \\
1400- \\
1800\end{array}$} & \multirow{2}{*}{$\begin{array}{l}\text { N1 } \\
<900\end{array}$} & \multirow{3}{*}{$\begin{array}{l}\text { Total } \\
36298\end{array}$} & \multirow{4}{*}{$\begin{array}{l}\begin{array}{l}\text { Influence } \\
(\%)\end{array} \\
23\end{array}$} \\
\hline \multirow{9}{*}{$\begin{array}{l}\frac{\lambda}{1} \\
\frac{\pi}{2} \\
0 \\
0 \\
0 \\
0 \\
0\end{array}$} & \multirow{3}{*}{$\begin{array}{l}\text { Elevation (m) } \\
\text { Area (ha) } \\
\text { Area }(\%)\end{array}$} & & & & & & \\
\hline & & 27534.2 & 4431.28 & 4331.08 & 1 & & \\
\hline & & 74.56 & 12 & 11.7 & - & 100 & \\
\hline & \multirow{3}{*}{$\begin{array}{c}\text { Slope }(\%) \\
\text { Area (ha) } \\
\text { Area }(\%)\end{array}$} & $0-13$ & $13-25$ & $25-40$ & $>40$ & \multirow[t]{2}{*}{36298} & \multirow[t]{3}{*}{6} \\
\hline & & 24752.8 & 10129.68 & 1333.08 & 82.44 & & \\
\hline & & 68.19 & 27.91 & 3.67 & 0.23 & 100 & \\
\hline & \multirow{3}{*}{$\begin{array}{r}\text { LULC (Type) } \\
\text { Area (ha) } \\
\text { Area (\%) }\end{array}$} & $\mathrm{AL}$ & OSL & WL & $\mathrm{F}$ & \multirow[t]{2}{*}{36298} & \multirow[t]{3}{*}{9} \\
\hline & & 26755.55 & 9184.05 & 138.3 & 9184.05 & & \\
\hline & & 73.71 & 25.30 & 0.38 & 0.61 & 100 & \\
\hline \multirow{9}{*}{ : } & \multirow{3}{*}{$\begin{array}{l}\text { Rainfall (mm) } \\
\text { Area (ha) } \\
\text { Area (\%) }\end{array}$} & $1200-1450$ & $1000-1200$ & $700-900$ & $<700$ & \multirow[t]{2}{*}{36298} & \multirow[t]{3}{*}{17} \\
\hline & & 7022.66 & 15790.47 & 4799.57 & 8685.3 & & \\
\hline & & 19.08 & 42.76 & 13.56 & 23.52 & 100 & \\
\hline & \multirow{2}{*}{$\begin{array}{l}\text { Temperature } \\
\left({ }^{0} \mathrm{C}\right)\end{array}$} & $15-16.5$ & $16.5-17.5$ & $17.5-19$ & $>20$ & \multirow[t]{2}{*}{36298} & \multirow[t]{3}{*}{13} \\
\hline & & 5957.18 & 4217.73 & 8690.02 & 17433.12 & & \\
\hline & $\begin{array}{l}\text { Area (ha) } \\
\text { Area (\%) }\end{array}$ & 16. 4 & 11.72 & 23.94 & 48.03 & 100 & \\
\hline & \multirow{3}{*}{$\begin{array}{c}\text { LGP (days) } \\
\text { Area (ha) } \\
\text { Area }(\%)\end{array}$} & $270-308$ & $270-240$ & $240-220$ & $<220$ & \multirow[t]{2}{*}{36298} & \multirow[t]{3}{*}{4} \\
\hline & & 13333.14 & 14247.36 & 4106.25 & 4611.25 & & \\
\hline & & 36.73 & 39.25 & 11.31 & 12.70 & 100 & \\
\hline & \multirow{3}{*}{$\begin{array}{l}\text { Soil texture } \\
\text { (type) } \\
\text { Area (ha) } \\
\text { Area (\%) }\end{array}$} & Cli & $\mathrm{CL}$ & SCL & - & \multirow[t]{2}{*}{36298} & \multirow[t]{3}{*}{11} \\
\hline & & 14446.97 & 6547.43 & 15303.6 & - & & \\
\hline & & 39.80 & 18.04 & 42.16 & - & 100 & \\
\hline & Soil & MW & - & - & I & 36298 & 7 \\
\hline & drainage(type) & 29479.6 & & - & 6818.4 & & \\
\hline & $\begin{array}{l}\text { Area (ha) } \\
\text { Area (\%) }\end{array}$ & - & 81.22 & 18.78 & - & 100 & \\
\hline & Soil depth(cm) & $70-100$ & $70-60$ & $60-50$ & $<50$ & 36298 & 5 \\
\hline & Area (ha) & 14587.36 & 14897.78 & - & 6813.08 & & \\
\hline & Area (\%) & 40.19 & 41.04 & - & 18.77 & 100 & \\
\hline & Soil PH & $5.5-7.5$ & $4.5-5.5$ & $4.5-4$ & $<4$ & 36298 & 3 \\
\hline & Area (ha) & 14558.85 & 14921.01 & - & 6818.14 & & \\
\hline & Area $(\%)$ & 40.11 & 41.11 & - & 18.78 & 100 & \\
\hline & Soil OC (\%) & - & $1.2-1.5$ & $0.8-1.2$ & $<1$ & 36298 & 2 \\
\hline$=$ & Area (ha) & - & 14921.01 & 14558.85 & 6818.14 & & \\
\hline क & Area (\%) & - & 41.11 & 40.11 & 18.78 & 100 & \\
\hline
\end{tabular}

Source: Field Work, 2018

Where $A L=$ agricultural land, OSL= open shrub land, $F=$ forest, $W=$ wood land, and $C l i=$ clay light, $C L=c l a y$ loam, $S C L=$ Sand clay loam, and $M W=$ moderately well; $I=$ imperfect 
Figure 22 Land suitability map of Teff and Barley
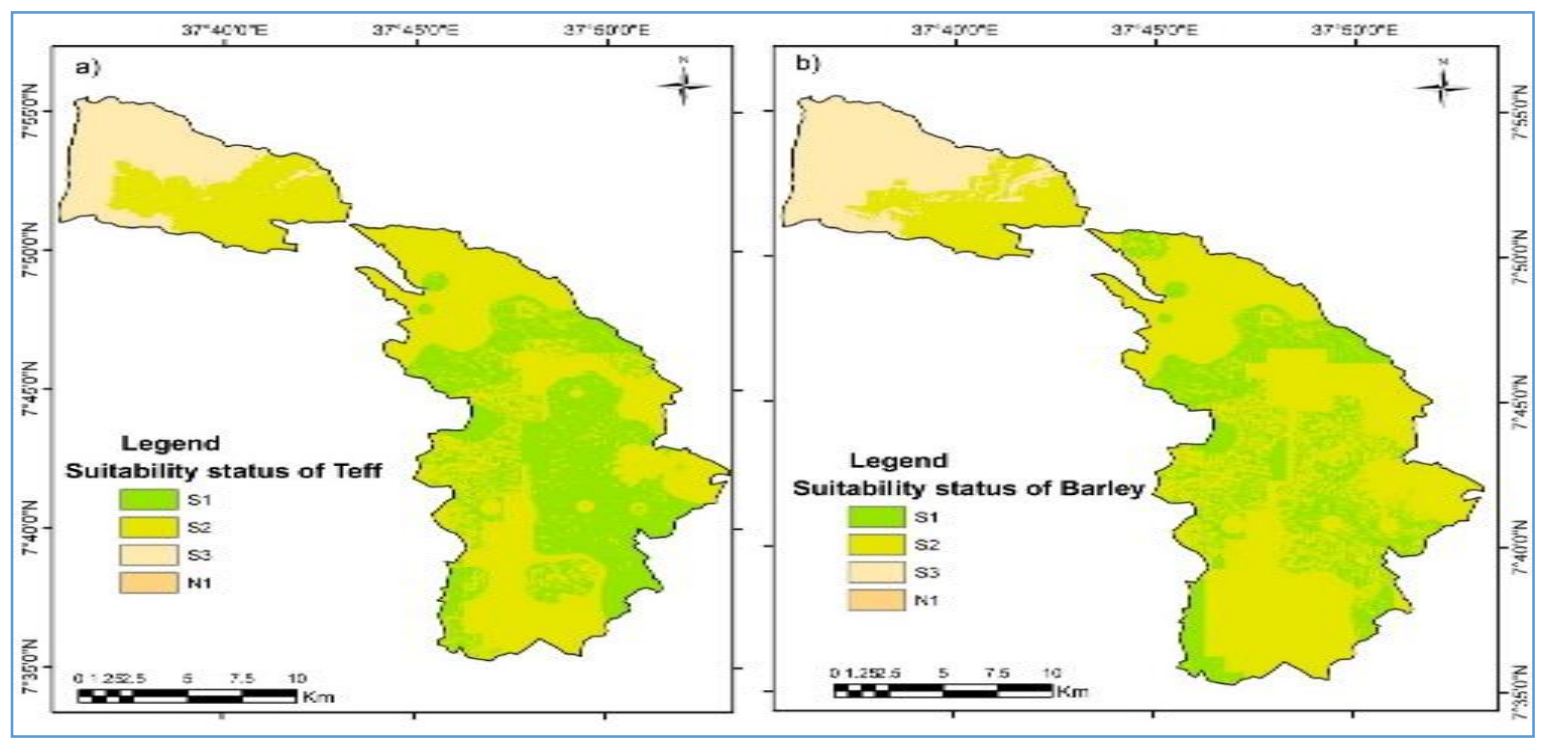

Source: Field Work, 2018

The suitability map of teff crop shows that 12038.22 hectare of the investigated area are highly suitable (S1), 19646.07 hectare moderately suitable (S2) and 4501.71 hectare marginally suitable (S3) and 122 hectare not suitable. On the other hand, the suitability map of barley crop shows that 7898.52 hectare of the investigated area are highly suitable (S1) 22830.08 hectare moderately suitable (S2), 5466.4 hectare marginally suitable (S3) and 103 hectare unsuitable for economic reasons (N1). The total resulting areas for both crops reveal the importance of agriculture in the study area, and the total area of teff suitability analysis 36186 hectare and the total area of barley 36195 hectare suitable and 215 hectare not suitable.

\section{Suitability Model Map}

Figure 23 Very high suitable for Teff a) and Barley b)
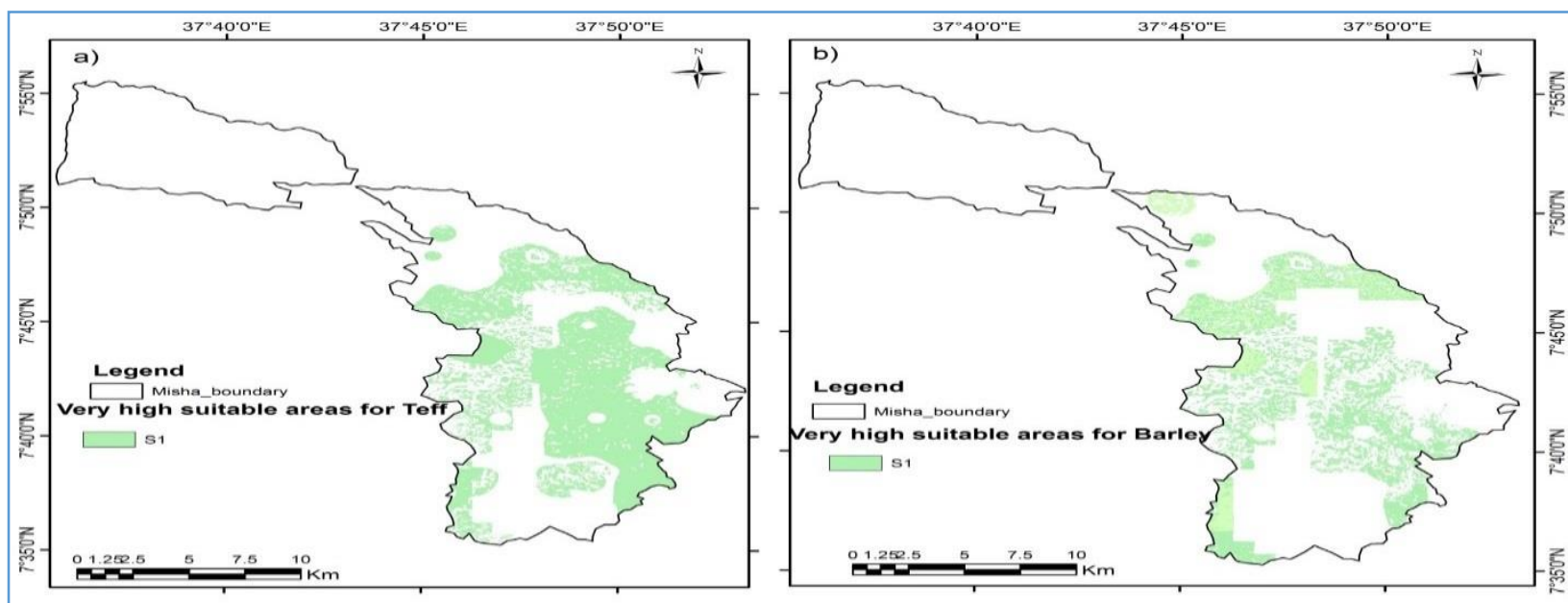

Source: Field Work, 2018 
Page $\mathbf{2 1}$ of $\mathbf{2 3}$

Table 11 Analyzed suitability classes for Teff and barley in hectare (ha)

\begin{tabular}{|l|l|l|l|l|}
\hline Suitability classes & Teff & Teff \% & Barley & Barley \% \\
\hline S1 & 12038.22 & $33.16 \%$ & 7898.52 & 21.76 \\
\hline S2 & 19646.07 & $(54.13 \%)$ & 22830.08 & 62.896 \\
\hline S3 & 4501.71 & $(12.40 \%)$ & 5466.4 & 15.05978 \\
\hline N1 & 112 & $0.31 \%)$ & 103 & 0.28 \\
\hline Total & $\mathbf{3 6 2 9 8}$ & $\mathbf{1 0 O} \%$ & $\mathbf{3 6 2 9 8}$ & $\mathbf{1 0 0} \%$ \\
\hline
\end{tabular}

Source: Field Work, 2018

\section{Conclusion}

Same of the moderately and marginally suitable land identified in the study area can improve their suitability by implementing different land management practices. It was also found that land suitability analysis for agricultural crops using a GIS environment is a strong tool towards measuring and evaluation of the long-term impacts of land suitability analysis on land productivity. However, the parameters used for land suitability analysis in this study were entirely physical; much improvement can be made if some socio-economic variables were considered. In addition, the land utilization types (LUTs) considered in this study were limited to two selected crops, whereas further studies can be made so as to increase the choice and identify the best alternative use of a specific landscape parcel for different LUTs by considering bean. Pean, cash crops, and livestock management. In general percale land of teff $33.16 \%$ and barely in $21.76 \%$ of land high suitable for the production of selected crops in the district. Training and awareness creation program provided by the Government and NGO should help and inform the farmers in order to adopt rotational grazing field to reduce over grazing. GIS and Remote sensing application not only decreases the factors introduced in to the investigation but also offers data processing procedure steps and reliable outcome through clear cut steps of procedure which could be updated.

\section{References}

[1] J. Davison, "Observation on Commercial Teff Production i Navada," Navafa Cooperatives Fact, pp. 07-29, 2007.

[2] Lutz,Wolfgang ,KC,Samir, "Demography and Human Development :Education and Population projection," UNDP, New York, 2013.

[3] FAO, "Guidelines for land-use planning," FAO Development Series No. 1, no. Series No. 1, 2013.

[4] Hurni H, "Agro-ecological belts of Ethiopia: Explanatory notes on three maps at a scale of 1:1,000,000," Research Report in Soil Conservation Program, pp. 3-20, 2004. 
[5] Infomineo, "Agriculture in Ethiopia: africa agricalture," Infomineo , 2015.

[6] A. R. Mohamed A. E, "Assesment of land suitablity and capablty by integrating remote sensing and GIS for agriculture in Chamarajanga district, Karanataka, India," The Egyptian Journal of Remote Sensing and Space Sciences., vol. 19, pp. 25-141, 2016.

[7] FAO, "A Framework for Land Evaluation: Soils Bulletin: 32," Food and Agriculture Organization of the United Nations,, Rome, 1976.

[8] FAO, "Ethiopian geomorphology and soils (1:1,000,000 scales).," Assistance to Land Use Planning, addis abeba , 1984.

[9] Natali R. Mustafa, Ward de Winter, Frank van Iren \& Robert Verpoorte, "Initiation, growth and cryopreservation of plant cell suspension cultures," Nature Protocol, vol. 6, no. 6, pp. 715742, 2011.

[10] A. Birhan, "Agronomic and Economic Effects of Blended Fertilizers Under Planting Method On Yield And Yield Components Of Teff in Wereda Laelay Maychew, Central Tigray, Ethiopia," Journal of Economics and Agricultural Development, 2012.

[11] USAID, “Southern Nation, Nationalities and People's Region, Ethiopia Livelihood Profiles:Fews Net Activity," USAID, Hawasaa , 2006.

[12] E. The Ministry of Agriculture, "Soil Conservation Research Programme Ethiopia:Agroecological Belts of Ethiopia Explanatory notes on three maps at a scale of 1:1,000,000," Centre for Development and Environment University of Bern, Switzerland in association with The Ministry of Agriculture, Ethiopia, pp. 1-20, 1998.

[13] Samo Drobne and Anka Lisec, "Multi-attribute Decision Analysis in GIS: Weighted Linear Combination and Ordered Weighted Averaging," Informatica, vol. 33 , p. 459-474, 2009.

[14] J. Malczewski, “Ordered weighted averaging with fuzzy quantifiers: GIS-based multi criteria evaluation for land-use suitability analysis.," International Journal of Applied Earth Observation and Geoinformation, pp. 270-277, 2006.

[15] T. L. Saaty, "Decision making with the analytic hirarchy process," International journal Journal of servivice sciences, vol. 1, no. 1 , pp. 88-98, 2008.

\section{Acknowledgments}

Acknowledgment goes to the local people, government Misha woreda Agricultural office experts and administrators, whole of Geography and Environmental Studies department staffs of Jimma University, central statically agency(CSA),Ethiopia Mapping Agency(EMA) who have collaborated with at a time of data collection of the study.

\section{Appendix A}




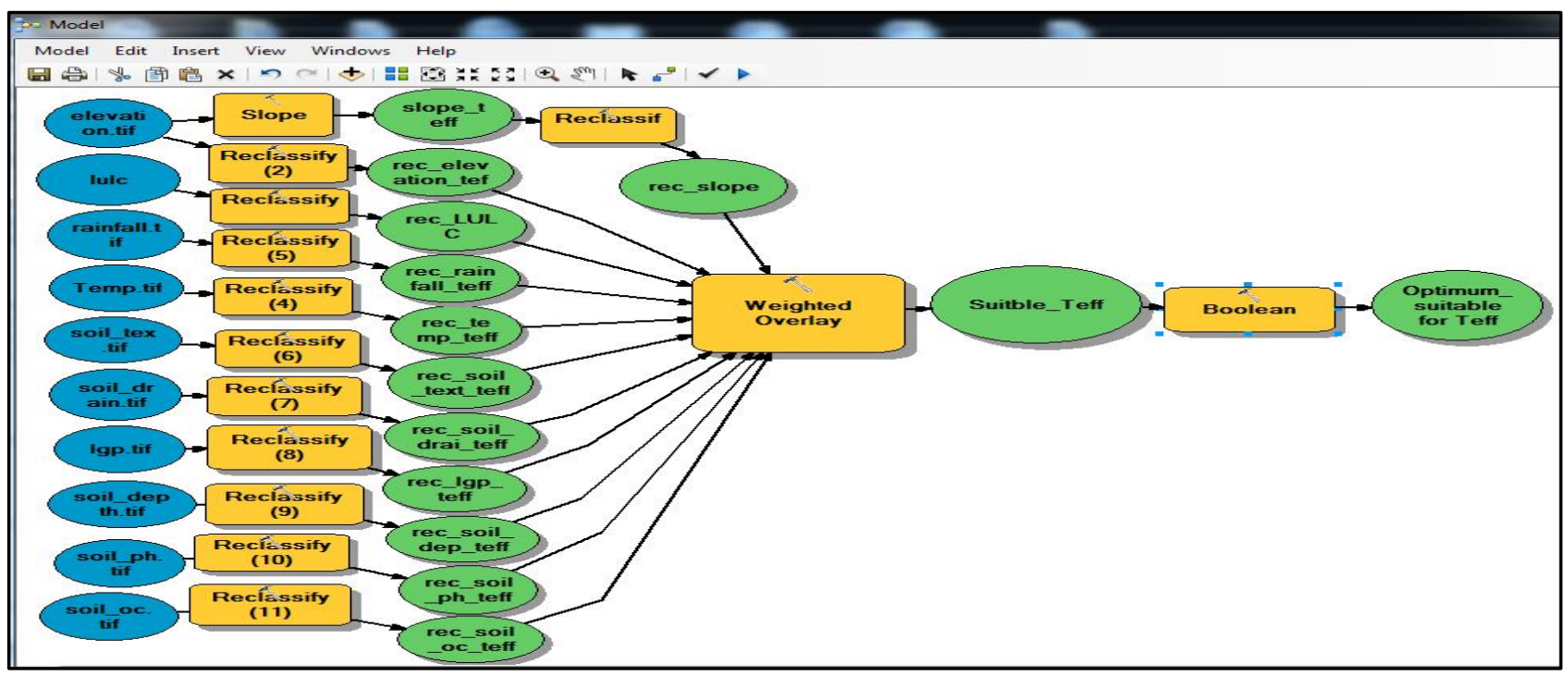

Figure 25 Modeler procedure used for barley suitability analysis.

\section{Appendix B}

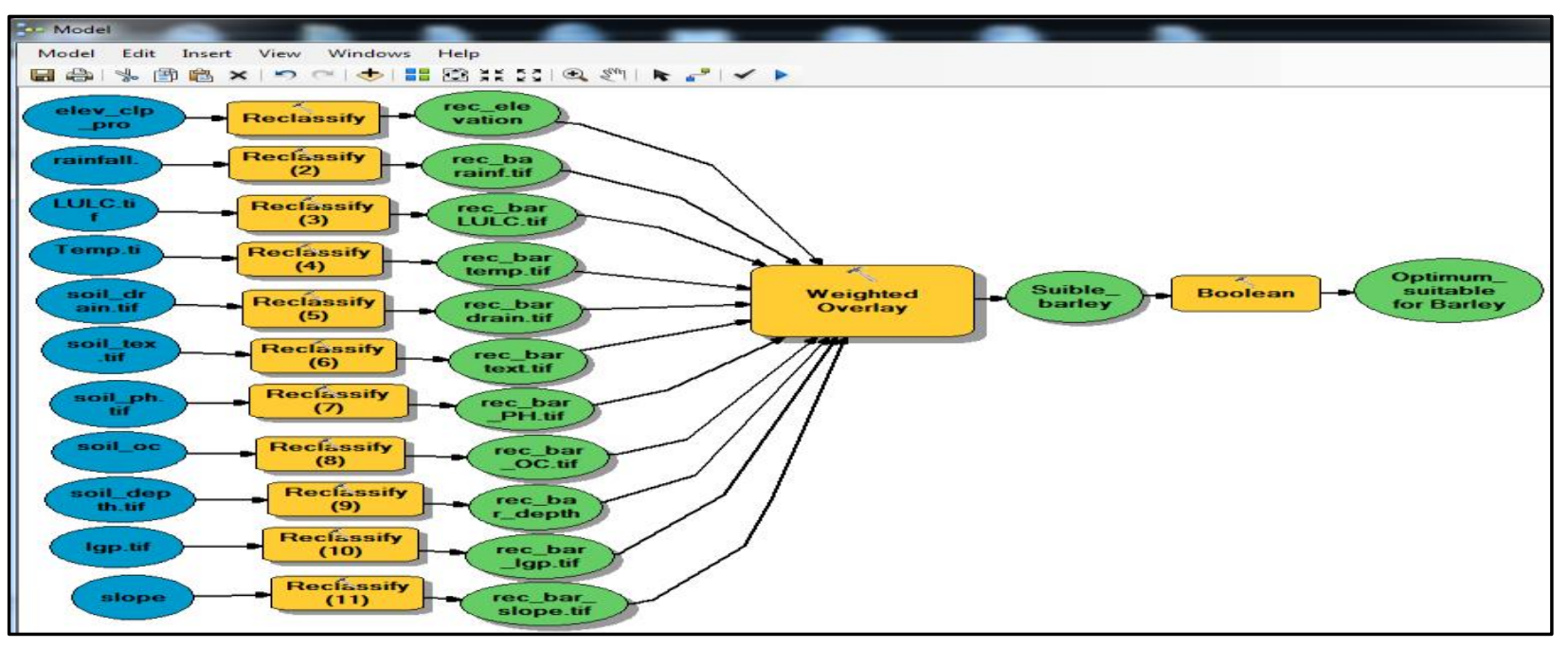

